Catalysis

Elsevier Editorial System(tm) for Journal of

Manuscript Draft

Manuscript Number: JCAT-15-802R5

Title: Carbon dioxide methanation over Ni catalysts supported on various metal oxides

Article Type: SI:CO2 conversion

Keywords: carbon dioxide methanation; nickel catalyst; basic property; in situ infrared spectroscopy

Corresponding Author: Dr. Hiroki Muroyama, PhD

Corresponding Author's Institution: Graduate School of Engineering, Kyoto University

First Author: Hiroki Muroyama, PhD

Order of Authors: Hiroki Muroyama, PhD; Yuji Tsuda; Toshiki Asakoshi; Hasan Masitah; Takeou Okanishi; Toshiaki Matsui; Koichi Eguchi

Manuscript Region of Origin: JAPAN

Abstract: Carbon dioxide methanation is well known to offer some advantages and be catalyzed by $\mathrm{Ru}, \mathrm{Rh}, \mathrm{Pd}$, and $\mathrm{Ni}$. In this study, Ni catalysts supported on various metal oxides were fabricated and their catalytic activity for CO2 methanation was evaluated. The Co2 conversion for most of catalysts drastically increased at $225-250{ }^{\circ} \mathrm{C}$ and reached a maximal value at 300-350 ${ }^{\circ} \mathrm{C}$. The order of $\mathrm{CH} 4$ yield at $250{ }^{\circ} \mathrm{C}$ was as follows; $\mathrm{Ni} / \mathrm{Y} 2 \mathrm{O} 3>\mathrm{Ni} / \mathrm{Sm} 2 \mathrm{O} 3>\mathrm{Ni} / \mathrm{ZrO} 2>\mathrm{Ni} / \mathrm{CeO} 2>\mathrm{Ni} / \mathrm{Al} 2 \mathrm{O} 3>\mathrm{Ni} / \mathrm{La} 2 \mathrm{O} 3$. The catalytic activity could be partly explained by the basic property of the catalysts. Moreover, the chemical species formed on the catalyst surface during $\mathrm{CO} 2$ methanation were examined by in situ infrared spectroscopy. From the obtained results, the difference in the activity depending on the support material of $\mathrm{Ni}$ catalysts was discussed. 
July 11, 2016

Dear Prof. Christophe Copéret,

We are sending herewith the response to editor comment and revised manuscript entitled "Carbon dioxide methanation over $\mathrm{Ni}$ catalysts supported on various metal oxides" by $\mathrm{H}$. Muroyama et al., which we should like to submit for publication as a research paper in Journal of Catalysis: Catalytic $\mathrm{CO}_{2}$ conversion processes to fuels and other small molecules.

Please let me know of your decision at your earliest convenience.

Yours sincerely,

Hiroki Muroyama/Assistant Professor

Department of Energy and Hydrocarbon Chemistry

Graduate School of Engineering

Kyoto University

Nishikyo-ku, Kyoto 615-8510, Japan

Phone: +81-75-383-2523, FAX: +81-75-383-2521

E-mail: muroyama.hiroki.5c@kyoto-u.ac.jp 


\section{Revision Notes}

Journal of Catalysis

Ms. No.: JCAT-15-802R4

Editor:

The authors would like to appreciate your fruitful comments. We modified the manuscript with red-letter.

After reading the revised manuscript, it may become suitable for publication in J. Catal. However, the manuscript presents mainly light-off curve and hardly any data regarding testing the catalysts under constant temperature regime. To become suitable for J. Catal. one expect to see additional test regarding the performance of the catalyst (conv. vs. time but also selectivity vs. time; it is also essential that the catalyst tests under kinetic regime have to be included as they provide information about the catalyst and the catalyst life time).

A. The durability tests for the $\mathrm{Ni} / \mathrm{Al}_{2} \mathrm{O}_{3}$ and $\mathrm{Ni} / \mathrm{Sm}_{2} \mathrm{O}_{3}$ catalysts were also carried out at $300{ }^{\circ} \mathrm{C}$ and $20,000 \mathrm{l} \mathrm{kg}^{-1} \mathrm{~h}^{-1}$. The time courses of $\mathrm{CO}_{2}$ conversion, and $\mathrm{CH}_{4}$ and $\mathrm{CO}$ yields over the Ni/ $\mathrm{Al}_{2} \mathrm{O}_{3}$, $\mathrm{Ni} / \mathrm{Y}_{2} \mathrm{O}_{3}$, and $\mathrm{Ni} / \mathrm{Sm}_{2} \mathrm{O}_{3}$ catalysts are shown in the revised manuscript. The performance of $\mathrm{Ni} / \mathrm{Al}_{2} \mathrm{O}_{3}$ was stable within $48 \mathrm{~h}$. The $\mathrm{CO}$ yields were quite higher than those for $\mathrm{Ni} / \mathrm{Y}_{2} \mathrm{O}_{3}$. In contrast, the $\mathrm{CO}_{2}$ conversion over $\mathrm{Ni} / \mathrm{Sm}_{2} \mathrm{O}_{3}$ catalyst significantly decremented accompanied by the decreases in $\mathrm{CH}_{4}$ and $\mathrm{CO}$ yields. It is well-known that the degradation of catalysts is derived from the carbon deposition and the sintering of Ni particles. Then, the fresh (reduced) and spent samples for each catalyst were examined by Raman spectroscopy and XRD. No Raman band assigned to deposited carbon was confirmed for all the samples. Moreover, no specific enlargement of $\mathrm{Ni}$ crystallite during the durability test was observed for each catalyst from XRD analysis. Thus, the obvious degradation factors are not identified at the present stage, and further investigation is required.

The holding time in the evaluation of catalytic performance against temperature was added to the experimental part in the revised manuscript because it was revealed that the catalyst performance was not stable for $\mathrm{Ni} / \mathrm{Sm}_{2} \mathrm{O}_{3}$. 


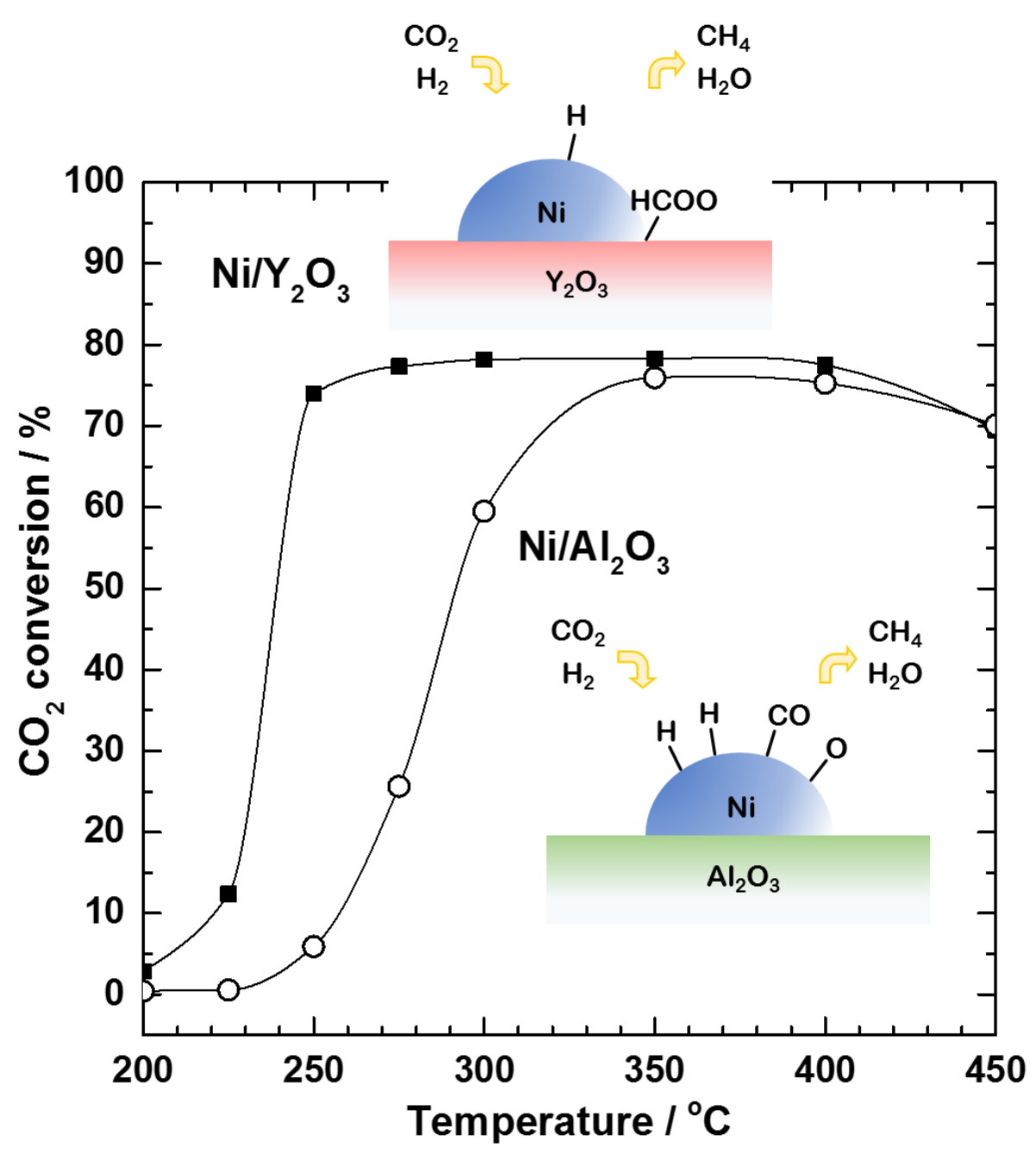




\section{Research highlights}

Nickel catalysts supported on various metal oxides were prepared.

The activity of nickel catalysts for $\mathrm{CO}_{2}$ methanation was evaluated.

The $\mathrm{Ni} / \mathrm{Y}_{2} \mathrm{O}_{3}$ catalyst exhibited the highest activity.

The reaction mainly proceeded via the formation of formate over $\mathrm{Ni} / \mathrm{Y}_{2} \mathrm{O}_{3}$. 
Carbon dioxide methanation over Ni catalysts supported on various metal oxides

Hiroki Muroyama*, Yuji Tsuda, Toshiki Asakoshi, Hasan Masitah, Takeou Okanishi, Toshiaki Matsui, and Koichi Eguchi

Department of Energy and Hydrocarbon Chemistry, Graduate School of Engineering, Kyoto University, Nishikyo-ku, Kyoto 615-8510, Japan

\begin{abstract}
Carbon dioxide methanation is well known to offer some advantages and be catalyzed by $\mathrm{Ru}, \mathrm{Rh}, \mathrm{Pd}$, and $\mathrm{Ni}$. In this study, $\mathrm{Ni}$ catalysts supported on various metal oxides were fabricated and their catalytic activity for $\mathrm{CO}_{2}$ methanation was evaluated. The $\mathrm{CO}_{2}$ conversion for most of catalysts drastically increased at 225-250 ${ }^{\circ} \mathrm{C}$ and reached a maximal value at $300-350{ }^{\circ} \mathrm{C}$. The order of $\mathrm{CH}_{4}$ yield at $250{ }^{\circ} \mathrm{C}$ was as follows; Ni/ $\mathrm{Y}_{2} \mathrm{O}_{3}>$ $\mathrm{Ni} / \mathrm{Sm}_{2} \mathrm{O}_{3}>\mathrm{Ni} / \mathrm{ZrO}_{2}>\mathrm{Ni} / \mathrm{CeO}_{2}>\mathrm{Ni} / \mathrm{Al}_{2} \mathrm{O}_{3}>\mathrm{Ni} / \mathrm{La}_{2} \mathrm{O}_{3}$. The catalytic activity could be partly explained by the basic property of the catalysts. Moreover, the chemical species formed on the catalyst surface during $\mathrm{CO}_{2}$ methanation were examined by in situ infrared spectroscopy. From the obtained results, the difference in the activity depending on the support material of Ni catalysts was discussed.
\end{abstract}

Keywords: carbon dioxide methanation, nickel catalyst, basic property, in situ infrared spectroscopy

* Corresponding author. Tel.: +81-75-383-2523; fax: +81-75-383-2521

E-mail address: muroyama.hiroki.5c @kyoto-u.ac.jp 


\section{Introduction}

At present, human beings globally face serious energy and environmental issues. They have produced an enormous energy with a use of fossil fuel accompanied with a significant development of industries. The human activities, however, have induced several climate changes on the earth. The global warming originates from the greenhouse effect gases such as carbon dioxide $\left(\mathrm{CO}_{2}\right)$, nitrous oxide $\left(\mathrm{N}_{2} \mathrm{O}\right)$, methane $\left(\mathrm{CH}_{4}\right)$, fluorocarbons, and chlorofluorocarbons. The $\mathrm{CO}_{2}$ concentration in the atmosphere has increased rapidly since the Industrial Revolution, and achieved ca. 400ppm. At the same time, the depletion of fossil fuel has been concerned due to its huge consumption. Then, the utilization technologies of renewable energy such as solar, wind power, and biomass have been developed strenuously so as to break the heavy reliance on fossil fuel. Among them, hydrogen produced from the renewable energy has attracted much attention as a promising energy medium in the sustainable energy society. Especially, the recent development of fuel cells has enhanced the importance of hydrogen. However, the low volume density and the difficulty in storage and transportation obstruct the practical utilization of hydrogen. Thus, reactions of $\mathrm{CO}_{2}$ and hydrogen to form hydrocarbons and alcohols have been extensively investigated to overcome the above-mentioned issues. These processes correspond to the recycling of carbon source and the utilization of synthesized fuels makes no contribution to the increase in $\mathrm{CO}_{2}$ emission amount. Furthermore, the synthesized fuels serve as hydrogen storage media and are utilized in order to produce hydrogen at consuming areas.

Methane is an important chemical feedstock as well as a fuel for the power generation by gas turbines. Because it is a major component of natural gas, the handling and infrastructure for storage and transportation of methane are well established. The methanation reaction of $\mathrm{CO}_{2}$, which is also called as the Sabatier reaction, proceeds as:

$$
\mathrm{CO}_{2}+4 \mathrm{H}_{2} \rightarrow \mathrm{CH}_{4}+2 \mathrm{H}_{2} \mathrm{O} \quad \Delta G=-114 \mathrm{~kJ} \mathrm{~mol}^{-1}
$$

Although this process is thermodynamically favorable, there are significant kinetic limitations to reduce the fully-oxidized carbon to methane $[1,2]$. Thus, various catalysts have been developed for the promotion of $\mathrm{CO}_{2}$ methanation. Metal catalysts of $\mathrm{Ru}, \mathrm{Rh}, \mathrm{Pd}$, and $\mathrm{Ni}$ are well known to be active in this reaction [3-23]. These metal catalysts are supported on metal oxides (e.g. $\mathrm{Al}_{2} \mathrm{O}_{3}, \mathrm{SiO}_{2}$, zeolites, $\mathrm{TiO}_{2}, \mathrm{CeO}_{2}$, and $\mathrm{CeO}_{2}-\mathrm{ZrO}_{2}$ ) [3-18]. The precious metal catalysts possess better activity than $\mathrm{Ni}$ one. Thampi et al. reported the $\mathrm{CH}_{4}$ formation over 
the $\mathrm{Ru} / \mathrm{TiO}_{2}$ catalyst at room temperature and atmospheric pressure [3]. However, they are not suitable for the industrial application due to their high cost. Thus, it is necessary to find Ni catalysts with high activity and durability for $\mathrm{CO}_{2}$ methanation.

Considerable effort has been also devoted to elucidating $\mathrm{CO}_{2}$ methanation mechanism $[4,5,9,14-21]$. Although the methanation reaction over metal catalysts has been studied for a long time, discussion on the mechanism has not yet reached a clear conclusion. The proposed reaction mechanisms are classified into two main categories from experimental and theoretical calculation studies. In one reaction pathway, carbon dioxide is converted to $\mathrm{CO}$ as an intermediate followed by $\mathrm{CO}$ methanation $[5,9,14,15,19,20]$. The other mechanism involves the formation of formate species as the main intermediate during the direct hydrogenation of $\mathrm{CO}_{2}[4$, $16-18,21]$.

The present study focused on $\mathrm{Ni}$ catalysts supported on various metal oxides for $\mathrm{CO}_{2}$ methanation. Although a number of studies have been performed for the development of highly-active Ni catalysts and the clarification of reaction mechanism, there are not many reports relating the catalytic activity to intermediates and species formed on $\mathrm{Ni}$ catalysts to the best of our knowledge $[14,16,17]$. In this study, therefore, we aimed to investigate the correlation between the catalytic activity and the species formed on $\mathrm{Ni}$ catalyst surface during $\mathrm{CO}_{2}$ methanation. Ni catalysts supported on various metal oxides were fabricated and their catalytic activities for the methanation reaction were examined. Moreover, the species formed in the reaction were compared for some catalysts.

\section{Experimental}

(i) Sample preparation

Nickel catalysts supported on metal oxides were synthesized by the impregnation method. Commercial $\mathrm{Ni}\left(\mathrm{NO}_{3}\right)_{2} \cdot 6 \mathrm{H}_{2} \mathrm{O}$ (Wako Pure Chemical Industries, Ltd.) was applied as a nickel source. The following oxides were employed as support materials: $\mathrm{Al}_{2} \mathrm{O}_{3}$ (AKP G-015, Sumitomo Chemical Co., Ltd.), $\mathrm{Y}_{2} \mathrm{O}_{3}$ (Wako Pure Chemical Industries, Ltd.), $\mathrm{ZrO}_{2}$ (Daiichi Kigenso Kagaku Kogyo Co., Ltd.), $\mathrm{La}_{2} \mathrm{O}_{3}$ (Shin-Etsu Chemical Co., Ltd.), $\mathrm{CeO}_{2}$ (JRC-CEO1, The Catalytic Society of Japan), and $\mathrm{Sm}_{2} \mathrm{O}_{3}$ (Wako Pure Chemical 
Industries, Ltd.). The nickel nitrate was dissolved in pure water at room temperature. The support material was added into the aqueous solution. The mixture was kept on a steam bath at $80{ }^{\circ} \mathrm{C}$ until the solution was evaporated. The resulting powder was calcined at $600{ }^{\circ} \mathrm{C}$ for $2 \mathrm{~h}$ in air. The Ni loading amount was fixed at 10 $\mathrm{wt} \%$.

(ii) Characterization

The crystal structure of the samples was analyzed by X-ray diffraction (XRD, Rigaku, Ultima IV X-ray diffractometer) equipped with high-speed detector (D/tex Ultra). The typical working condition was $40 \mathrm{kV}$ and $40 \mathrm{~mA}$ with a scanning rate of $20^{\circ} \mathrm{min}^{-1}$. The volume per unit weight of as-prepared samples was evaluated by Archimedes' methode (Quantachrome Instruments, Ultrapycnometer 1000). The morphology of Ni particles in catalyst was observed by using a transmission electron microscope (TEM, JEOL, JEM-2100F) equipped with an energy dispersive X-ray spectrometer (EDS, JEOL JED-2300T). Prior to the TEM observation, the sample was reduced at $600{ }^{\circ} \mathrm{C}$ for $3 \mathrm{~h}$ with a supply of $10 \% \mathrm{H}_{2}-90 \% \mathrm{~N}_{2}$ at a flow rate of $100 \mathrm{ml} \mathrm{min}^{-1}$. The basic property of the sample was examined by $\mathrm{CO}_{2}$ temperature programmed desorption $\left(\mathrm{CO}_{2}-\mathrm{TPD}\right.$, BEL Japan, BELCAT-A). After reducing at $600{ }^{\circ} \mathrm{C}$ for $2 \mathrm{~h}$ in $\mathrm{H}_{2}\left(30 \mathrm{ml} \mathrm{min}^{-1}\right)$ and cooling to $50{ }^{\circ} \mathrm{C}$ in $\mathrm{He}$, carbon dioxide was supplied. Subsequently, the sample was heated to $600{ }^{\circ} \mathrm{C}$ in $\mathrm{He}$ and the desorbed $\mathrm{CO}_{2}$ was detected by a themal conductivity detector. The reduction behavior of catalysts was evaluated by temperature-programmed reduction (TPR, BEL Japan, BELCAT). The sample was fixed in a quartz tube reactor, and then a gaseous mixture of $4 \% \mathrm{H}_{2} / \mathrm{Ar}$ was fed to the reactor. The temperature was raised at a rate of $10{ }^{\circ} \mathrm{C} \min ^{-1}$ from 50 to $1000{ }^{\circ} \mathrm{C}$, and the rate of hydrogen consumption was measured by a thermal conductivity detector (TCD). The species formed over catalysts was analyzed with the diffuse reflectance infrared Fourier transform (DRIFT) spectroscopy. A reaction cell capped with ZnSe window was used for in situ measurement. First, the powder sample was set in the reaction cell and reduced at $600{ }^{\circ} \mathrm{C}$ for $1.5 \mathrm{~h}$ in $5 \% \mathrm{H}_{2}-95 \% \mathrm{~N}_{2}\left(100 \mathrm{ml} \mathrm{min}^{-1}\right)$. After cooling to $200{ }^{\circ} \mathrm{C}$ in $\mathrm{N}_{2}$, a reaction gas was fed to the sample at a rate of $100 \mathrm{ml} \mathrm{min}^{-1}$. Gaseous mixtures of $4 \% \mathrm{CO}_{2}-96 \% \mathrm{~N}_{2}, 4 \%$ $\mathrm{CO}_{2}-16 \% \mathrm{H}_{2}-80 \% \mathrm{~N}_{2}$, and $5 \% \mathrm{H}_{2}-95 \% \mathrm{~N}_{2}$ were supplied as reaction gases. After measuring a background spectrum at $200{ }^{\circ} \mathrm{C}$ in $\mathrm{N}_{2}$, the sample was held sequentially (i) in the $\mathrm{CO}_{2}-\mathrm{N}_{2}$ atmosphere for $30 \mathrm{~min}$, (ii) in the $\mathrm{CO}_{2}-\mathrm{H}_{2}-\mathrm{N}_{2}$ atmosphere for $30 \mathrm{~min}$, and (iii) in the $\mathrm{H}_{2}-\mathrm{N}_{2}$ atmosphere for $2 \mathrm{~h}$. The spectra were recorded 50 
scans at a resolution of $4 \mathrm{~cm}^{-1}$ using an infrared spectrometer equipped with an MCT detector (NICOLET 8700, Thermo Fisher Scientific). Difference spectra corresponding to the formed species were collected by subtracting those recorded in the reaction gas to that obtained in $\mathrm{N}_{2}$.

(iii) Catalytic activity

The prepared powder was pelletized and pulverized to 10-18 mesh. Prior to the evaluation of catalytic test, the sample was reduced at $600{ }^{\circ} \mathrm{C}$ for $3 \mathrm{~h}$ with a supply of $10 \% \mathrm{H}_{2}-90 \% \mathrm{~N}_{2}$ at a flow rate of $100 \mathrm{ml} \mathrm{min}^{-1}$. The catalytic test was conducted with a use of a fixed-bed reactor under atmospheric pressure. The temperature dependence of catalytic performance was examined with a supply of $10 \% \mathrm{CO}_{2}-40 \% \mathrm{H}_{2}-50 \% \mathrm{~N}_{2}$ at space velocities of 20,000 and $30,000 \mathrm{l} \mathrm{kg}^{-1} \mathrm{~h}^{-1}$ in the heating process. At each temperature, the sample was kept for 30 min. The durability of catalyst was evaluated at $300{ }^{\circ} \mathrm{C}$ by feeding $10 \% \mathrm{CO}_{2}-40 \% \mathrm{H}_{2}-50 \% \mathrm{~N}_{2}$ at 20,0001 $\mathrm{kg}^{-1} \mathrm{~h}^{-1}$. The composition of outlet gas was analyzed by on-line gas chromatograph with a thermal conductivity detector (VARIAN, CP-4900). The $\mathrm{CO}_{2}$ conversion, and $\mathrm{CH}_{4}$ and $\mathrm{CO}$ yields were defined as follows:

$\mathrm{CO}_{2}$ conversion $(\%)=\frac{\left[\mathrm{CH}_{4}\right]+[\mathrm{CO}]}{\left[\mathrm{CH}_{4}\right]+[\mathrm{CO}]+\left[\mathrm{CO}_{2}\right]} \times 100$

$\mathrm{CH}_{4}$ yield $(\%)=\frac{\left[\mathrm{CH}_{4}\right]}{\left[\mathrm{CH}_{4}\right]+[\mathrm{CO}]+\left[\mathrm{CO}_{2}\right]} \times 100$

CO yield $(\%)=\frac{[\mathrm{CO}]}{\left[\mathrm{CH}_{4}\right]+[\mathrm{CO}]+\left[\mathrm{CO}_{2}\right]} \times 100$

where $[X]\left(X=\mathrm{CH}_{4}, \mathrm{CO}, \mathrm{CO}_{2}\right)$ represents the molar fraction of $X$ component in the outlet gas.

\section{Results and discussion}

The crystal structure of samples was examined before and after reducing at $600{ }^{\circ} \mathrm{C}$ for $3 \mathrm{~h}$ in $10 \%$ $\mathrm{H}_{2}-90 \% \mathrm{~N}_{2}$. Before the reduction treatment, the diffraction lines of $\mathrm{NiO}$ and support material were confirmed for the $\mathrm{Ni} / \mathrm{Al}_{2} \mathrm{O}_{3}, \mathrm{Ni} / \mathrm{ZrO}_{2}$, and $\mathrm{Ni} / \mathrm{CeO}_{2}$ catalysts, while the patterns of the $\mathrm{Ni} / \mathrm{Y}_{2} \mathrm{O}_{3}$ and $\mathrm{Ni} / \mathrm{Sm}_{2} \mathrm{O}_{3}$ catalysts were attributed to those of metal oxide support. The $\mathrm{Ni} / \mathrm{La}_{2} \mathrm{O}_{3}$ catalyst was composed of $\mathrm{La}(\mathrm{OH})_{3}$ and $\mathrm{LaNiO}_{3}$. The $\mathrm{La}(\mathrm{OH})_{3}$ phase may be formed via the reaction between $\mathrm{La}_{2} \mathrm{O}_{3}$ and water at the preparation step. Fig. 1 shows the XRD patterns of reduced Ni catalysts. The metallic Ni phase was detected for all the catalysts other than 
$\mathrm{Ni} / \mathrm{Sm}_{2} \mathrm{O}_{3}$. The pattern of $\mathrm{Ni} / \mathrm{La}_{2} \mathrm{O}_{3}$ catalyst revealed that the $\mathrm{LaNiO}_{3}$ phase was decomposed to form the $\mathrm{Ni}$ metal by the reduction treatment. The Ni particles of reduced catalysts were examined by TEM observation. The Ni particles over the respective support materials were observed in the following size range; $\mathrm{Ni} / \mathrm{Al}_{2} \mathrm{O}_{3}: 6.0-18$ $\mathrm{nm}, \mathrm{Ni} / \mathrm{Y}_{2} \mathrm{O}_{3}: 4.9-18 \mathrm{~nm}, \mathrm{Ni} / \mathrm{ZrO}_{2}: 18-210 \mathrm{~nm}, \mathrm{Ni} / \mathrm{La}_{2} \mathrm{O}_{3}: 5.3-23 \mathrm{~nm}, \mathrm{Ni} / \mathrm{CeO}_{2}: 8.1-68 \mathrm{~nm}$, and Ni/Sm $\mathrm{O}_{3}$ : $4.3-16 \mathrm{~nm}$. Some agglomerated Ni particles were located over the support material for the $\mathrm{Ni} / \mathrm{ZrO}_{2}$ and $\mathrm{Ni} / \mathrm{CeO}_{2}$ catalysts.

The $\mathrm{H}_{2}-\mathrm{TPR}$ profiles of the Ni catalysts are shown in Fig. 2. Most of Ni species in $\mathrm{Ni} / \mathrm{Y}_{2} \mathrm{O}_{3}, \mathrm{Ni} / \mathrm{ZrO}_{2}$, $\mathrm{Ni} / \mathrm{CeO}_{2}$, and $\mathrm{Ni} / \mathrm{Sm}_{2} \mathrm{O}_{3}$ catalysts was reduced up to $600{ }^{\circ} \mathrm{C}$, indicating that the $\mathrm{Ni}$ species was in the metallic state at the beginning of activity test. In contrast, the $\mathrm{Ni} / \mathrm{Al}_{2} \mathrm{O}_{3}$ catalyst was continuously reduced over $1000{ }^{\circ} \mathrm{C}$, and the reduction of $\mathrm{Ni} / \mathrm{La}_{2} \mathrm{O}_{3}$ needed high temperature of $750{ }^{\circ} \mathrm{C}$. It is known that the composite oxides such as $\mathrm{NiAl}_{2} \mathrm{O}_{4}$ and $\mathrm{LaNiO}_{3}$ are readily formed in these catalysts at the calcination process in air. Thus, hydrogen would be consumed for the reduction of nickel species in such composite oxides at high temperatures.

Fig. 3 shows the $\mathrm{CO}_{2}$ desorption behavior of the $\mathrm{Ni}$ catalysts after the reduction at $600{ }^{\circ} \mathrm{C}$ for $2 \mathrm{~h}$. The profile of $\mathrm{Ni} / \mathrm{ZrO}_{2}$ exhibited only a small amount of desorbed $\mathrm{CO}_{2}$. This catalyst scarcely possessed basic sites. The $\mathrm{CO}_{2}$ desorption was observed at $50-180{ }^{\circ} \mathrm{C}$ for $\mathrm{Ni} / \mathrm{CeO}_{2}$, indicating the existence of weak basic sites. A large amount of desorbed $\mathrm{CO}_{2}$ was detected in the wide temperature range for $\mathrm{Ni} / \mathrm{Al}_{2} \mathrm{O}_{3}$. The large specific surface area of this material $\left(141 \mathrm{~m}^{2} \mathrm{~g}^{-1}\right)$ should be one of the reasons for a number of basic sites. As in the case of the $\mathrm{Ni} / \mathrm{Al}_{2} \mathrm{O}_{3}$ catalyst, carbon dioxide was desorbed from $\mathrm{Ni} / \mathrm{La}_{2} \mathrm{O}_{3}$ in the wide temperature region, implying that the basic sites with several strengths were widespread on the catalyst surface. Especially, the $\mathrm{CO}_{2}$ desorption at $400-500{ }^{\circ} \mathrm{C}$ was more remarkable for $\mathrm{Ni}^{2} / \mathrm{La}_{2} \mathrm{O}_{3}$ than for the other samples. In contrast, no strongly-adsorbed $\mathrm{CO}_{2}$ was confirmed for the $\mathrm{Ni} / \mathrm{Y}_{2} \mathrm{O}_{3}$ and $\mathrm{Ni} / \mathrm{Sm}_{2} \mathrm{O}_{3}$ catalysts.

$\mathrm{CO}_{2}$ methanation reaction over the $\mathrm{Ni}$ catalysts was investigated at $200-450{ }^{\circ} \mathrm{C}$ in the heating process. The $\mathrm{CO}_{2}$ conversion, and $\mathrm{CH}_{4}$ and $\mathrm{CO}$ yields over the $\mathrm{Ni}$ catalysts supported on metal oxides at a low space velocity of 20,000 $\mathrm{l} \mathrm{kg}^{-1} \mathrm{~h}^{-1}$ are plotted in Fig. 4. The dashed lines in Figs. 4(a) and (b) correspond to the equilibrium value from the thermodynamic calculation. The $\mathrm{CO}_{2}$ conversion drastically increased at $225-250{ }^{\circ} \mathrm{C}$ and then reached a maximal value at $300-350{ }^{\circ} \mathrm{C}$ under this condition for most of the catalysts investigated. Subsequently, the value gradually decreased as elevating the reaction temperature. The $\mathrm{CH}_{4}$ yield also showed 
similar temperature dependence to the $\mathrm{CO}_{2}$ conversion (Fig. 4(b)). In the low temperature region, the $\mathrm{CO}_{2}$ conversion and $\mathrm{CH}_{4}$ yield were mostly coincident at each temperature for all the respective catalysts, indicating that $\mathrm{CO}_{2}$ methanation was highly selective to the $\mathrm{CH}_{4}$ formation. In Fig. 4(c), the $\mathrm{CO}$ yield significantly incremented above $350{ }^{\circ} \mathrm{C}$ accompanied with the decrease in $\mathrm{CH}_{4}$ yield. This phenomenon was mainly attributed to the reverse water gas shift reaction $\left(\mathrm{CO}_{2}+\mathrm{H}_{2} \mathrm{O} \rightarrow \mathrm{CO}+\mathrm{H}_{2}\right)$, which dominantly proceeds at higher temperatures. When the catalytic activity test was conducted with a constant weight of sample, the $\mathrm{Ni} / \mathrm{Y}_{2} \mathrm{O}_{3}$ catalyst exhibited the highest activity for the $\mathrm{CH}_{4}$ formation in the wide temperature range among the catalysts investigated and provided the $\mathrm{CH}_{4}$ yield of $80 \%$ at $300{ }^{\circ} \mathrm{C}$. On the other hand, the catalysts of $\mathrm{Ni} / \mathrm{Al}_{2} \mathrm{O}_{3}$ and $\mathrm{Ni} / \mathrm{La}_{2} \mathrm{O}_{3}$ were inferior in performance to the others, especially at low temperatures. Their low activities were partly attributable to the difficulty in the reduction of some nickel species in these catalysts at the reduction treatment, which was indicated in the $\mathrm{H}_{2}-\mathrm{TPR}$ measurements (see Fig. 2). Table 1 summarizes the volume per unit weight of as-prepared samples obtained based on the Archimedes' principle. Due to the fixed sample weight in the performance test, the contact time between the catalyst and the reactant gas was different from each other. The volume per unit weight of $\mathrm{Ni} / \mathrm{Y}_{2} \mathrm{O}_{3}$ was ca. 1.4 times larger than that of $\mathrm{Ni} / \mathrm{CeO}_{2}$, which had the lowest value of all. Then, the activity test of $\mathrm{Ni} / \mathrm{Y}_{2} \mathrm{O}_{3}$ was carried out at the low contact time to confirm its high catalytic performance (gray square symbols in Fig. 4). The space velocity was set at $30,000 \mathrm{l} \mathrm{kg}^{-1} \mathrm{~h}^{-1}$, which corresponded to the lowest contact time among all the conditions investigated. The $\mathrm{CO}_{2}$ conversion and $\mathrm{CH}_{4}$ yield over $\mathrm{Ni} / \mathrm{Y}_{2} \mathrm{O}_{3}$ decreased with an increase in the space velocity. However, compared with the others, the higher or comparable performance was obtained even at the higher space velocity. Thus, it could be concluded that the $\mathrm{Ni} / \mathrm{Y}_{2} \mathrm{O}_{3}$ catalyst possessed the superior activity for $\mathrm{CO}_{2}$ methanation. Note that there was a rough relationship between the $\mathrm{CH}_{4}$ yield and the basic property of the catalysts. For $\mathrm{Ni} / \mathrm{Y}_{2} \mathrm{O}_{3}$ and $\mathrm{Ni} / \mathrm{Sm}_{2} \mathrm{O}_{3}$ with the relatively high $\mathrm{CH}_{4}$ yield at 225 and $250{ }^{\circ} \mathrm{C}$, most of adsorbed $\mathrm{CO}_{2}$ was desorbed below $400{ }^{\circ} \mathrm{C}$ in the $\mathrm{CO}_{2}-\mathrm{TPD}$ measurement. In contrast, only a small amount of $\mathrm{CO}_{2}$ was converted to $\mathrm{CH}_{4}$ over the $\mathrm{Ni} / \mathrm{Al}_{2} \mathrm{O}_{3}$ and $\mathrm{Ni} / \mathrm{La}_{2} \mathrm{O}_{3}$ catalysts at these temperatures. Considering that these materials possessed the strong basic sites, the strongly-adsorbed $\mathrm{CO}_{2}$ may inhibit the progress of $\mathrm{CH}_{4}$ formation. Accordingly, the moderate basic sites would be one of the desired properties of $\mathrm{Ni}$ catalyst for the $\mathrm{CH}_{4}$ production from $\mathrm{CO}_{2}$ methanation. On the other hand, the $\mathrm{CO}$ yield of $\mathrm{Ni}$ catalysts was not related with this property. 
The durability tests for the $\mathrm{Ni} / \mathrm{Al}_{2} \mathrm{O}_{3}, \mathrm{Ni} / \mathrm{Y}_{2} \mathrm{O}_{3}$, and $\mathrm{Ni} / \mathrm{Sm}_{2} \mathrm{O}_{3}$ catalysts were carried out at $300{ }^{\circ} \mathrm{C}$ and $20,0001 \mathrm{~kg}^{-1} \mathrm{~h}^{-1}$. Fig. 5 shows the time courses of $\mathrm{CO}_{2}$ conversion, and $\mathrm{CH}_{4}$ and $\mathrm{CO}$ yields over the $\mathrm{Ni} / \mathrm{Al}_{2} \mathrm{O}_{3}$, $\mathrm{Ni} / \mathrm{Y}_{2} \mathrm{O}_{3}$, and $\mathrm{Ni} / \mathrm{Sm}_{2} \mathrm{O}_{3}$ catalysts. The performance of $\mathrm{Ni} / \mathrm{Al}_{2} \mathrm{O}_{3}$ was stable within $48 \mathrm{~h}$. For $\mathrm{Ni} / \mathrm{Y}_{2} \mathrm{O}_{3}$, the $\mathrm{CO}_{2}$ conversion slightly dropped from $77.0 \%$ to $74.2 \%$ with time. The CO yields were within $0.05 \%$ throughout this test, which were quite lower than those for $\mathrm{Ni} / \mathrm{Al}_{2} \mathrm{O}_{3}$. As a result, carbon dioxide could be selectively converted to $\mathrm{CH}_{4}$ in this durability test. In contrast, the $\mathrm{CO}_{2}$ conversion over $\mathrm{Ni} / \mathrm{Sm}_{2} \mathrm{O}_{3}$ catalyst significantly decremented accompanied with the decreases in $\mathrm{CH}_{4}$ and $\mathrm{CO}$ yields. It is well-known that the degradation of catalysts is derived from the carbon deposition and the sintering of Ni particles [22, 23]. Then, the fresh (reduced) and spent samples for each catalyst were examined by Raman spectroscopy and XRD. No Raman band assigned to deposited carbon was confirmed for all the samples. Moreover, no specific enlargement of Ni crystallite during the durability test was observed for each catalyst from XRD analysis. Thus, the obvious degradation factors are not identified at the present stage, and further investigation is required.

The species formed on the Ni catalyst during $\mathrm{CO}_{2}$ methanation was examined by in situ DRIFT spectroscopy to elucidate the reason for the difference in catalytic activity depending on the sample. The $\mathrm{Ni} / \mathrm{Y}_{2} \mathrm{O}_{3}, \mathrm{Ni} / \mathrm{Al}_{2} \mathrm{O}_{3}$, and $\mathrm{Ni} / \mathrm{La}_{2} \mathrm{O}_{3}$ catalysts were selected because these materials provided the significantly different catalytic performance as shown in Fig. 4. Fig. 6 displays the infrared spectra of species formed on $\mathrm{Ni} / \mathrm{La}_{2} \mathrm{O}_{3}, \mathrm{Ni} / \mathrm{Al}_{2} \mathrm{O}_{3}$, and $\mathrm{Ni} / \mathrm{Y}_{2} \mathrm{O}_{3}$ recorded at $200{ }^{\circ} \mathrm{C}$ after sequential holding (a) in the $\mathrm{CO}_{2}-\mathrm{N}_{2}$ atmosphere for 30 min, (b) in the $\mathrm{CO}_{2}-\mathrm{H}_{2}-\mathrm{N}_{2}$ atmosphere for $30 \mathrm{~min}$, and (c) in the $\mathrm{H}_{2}-\mathrm{N}_{2}$ atmosphere for $1 \mathrm{~min}$. The assignment of adsorption bands was conducted by reference to the infrared spectra of species formed on $\mathrm{Y}_{2} \mathrm{O}_{3}, \mathrm{CeO}_{2}-\mathrm{ZrO}_{2}$, $\mathrm{Al}_{2} \mathrm{O}_{3}, \mathrm{Ni} / \mathrm{CeO}_{2}-\mathrm{ZrO}_{2}$, and $\mathrm{Ni} / \mathrm{Al}_{2} \mathrm{O}_{3}$ under $\mathrm{CO}_{2}$-containing atmospheres or $\mathrm{CO}_{2}$ methanation conditions reported in the previous literatures $[9,16-18,24]$. In the spectra for $\mathrm{Ni} / \mathrm{La}_{2} \mathrm{O}_{3}$, the formed species was independent of the measurement atmospheres. Furthermore, no change in the spectra was confirmed during holding in $\mathrm{H}_{2}-\mathrm{N}_{2}$ for 2 h. The bands centered at $1570,1504,1423$, and $1315 \mathrm{~cm}^{-1}$ were assigned to carbonates on $\mathrm{La}_{2} \mathrm{O}_{3}$. Thus, the carbonate species were quite stable over $\mathrm{Ni} / \mathrm{La}_{2} \mathrm{O}_{3}$ under this condition. Six bands clearly appeared in the spectrum obtained under the $\mathrm{CO}_{2}$ atmosphere for $\mathrm{Ni} / \mathrm{Al}_{2} \mathrm{O}_{3}$. The broad bands at 2021 and $1851 \mathrm{~cm}^{-1}$ are attributed to linear $\mathrm{CO}$ species and two-fold bridged $\mathrm{CO}$ species located on Ni, respectively [9]. This implied that carbon dioxide was readily dissociated to form CO on the Ni particles. Hydrogen carbonates (1653, 1534, 
and $\left.1230 \mathrm{~cm}^{-1}\right)$ and carbonates $\left(1443 \mathrm{~cm}^{-1}\right)$ on the $\mathrm{Al}_{2} \mathrm{O}_{3}$ support were also detected [9, 17]. As hydrogen was introduced to the $\mathrm{CO}_{2}$ atmosphere, the bands of hydrogen carbonates and carbonates disappeared accompanied with the band formation of formate species on $\mathrm{Al}_{2} \mathrm{O}_{3}$ at 1595,1392 , and $1377 \mathrm{~cm}^{-1}$ [9]. The adsorption bands of CO species (2021 and $1832 \mathrm{~cm}^{-1}$ ) became more remarkable, which would indicate that the reverse water gas shift reaction was promoted by the water generated from $\mathrm{CO}_{2}$ methanation. Moreover, the band at $1906 \mathrm{~cm}^{-1}$ newly appeared, which has not been assigned specifically so far. Hu et al. observed an adsorption band at ca. 1912 $\mathrm{cm}^{-1}$ under $\mathrm{H}_{2}-\mathrm{CO}$ co-adsorption condition at $150-250^{\circ} \mathrm{C}$, which was ascribable to nickel carbonyl hydride [25]. It was also suggested that rhodium carbonyl hydride was formed on $\mathrm{Rh}$ catalysts under $\mathrm{H}_{2}-\mathrm{CO}_{2}$ atmosphere [26]. Thus, in this study, considering that the hydrogen introduction resulted in the band at $1906 \mathrm{~cm}^{-1}$, this might originate from nickel carbonyl hydride. The spectra scarcely changed for $1 \mathrm{~min}$ from the beginning of the supply of $5 \% \mathrm{H}_{2}-95 \% \mathrm{~N}_{2}$. The spectra for $\mathrm{Ni} / \mathrm{Y}_{2} \mathrm{O}_{3}$ mainly exhibited two broad bands in the $1700-1200 \mathrm{~cm}^{-1}$ range under the three conditions. In the $\mathrm{CO}_{2}$ atmosphere, the spectrum was composed of the bands of several carbonate-like species (carbonates and hydrogen carbonates) formed on $\mathrm{Y}_{2} \mathrm{O}_{3}$ [24]. Then, the subsequent supply of $\mathrm{CO}_{2}-\mathrm{H}_{2}-\mathrm{N}_{2}$ mixture resulted in the strong band of formate species at $1595 \mathrm{~cm}^{-1}$ accompanied with the disappearance of hydrogen carbonates $\left(1670\right.$ and $\left.1221 \mathrm{~cm}^{-1}\right)[16,17,24]$. As compared with the carbonate-like species, the intensity of absorption band of formate slightly decreased even in 1 min after stopping $\mathrm{CO}_{2}$ supply. The extremely small bands attributable to CO species were also detected at $2100-1800 \mathrm{~cm}^{-1}$ and seemed to show the same behavior against the atmospheres as in the case of $\mathrm{Ni} / \mathrm{Al}_{2} \mathrm{O}_{3}$.

Subsequently, the variation of band intensity in the $\mathrm{H}_{2}$ atmosphere was compared for $\mathrm{Ni} / \mathrm{Al}_{2} \mathrm{O}_{3}$ and $\mathrm{Ni} / \mathrm{Y}_{2} \mathrm{O}_{3}$. Fig. 7 shows the infrared spectra of species formed on $\mathrm{Ni} / \mathrm{Al}_{2} \mathrm{O}_{3}$ and $\mathrm{Ni} / \mathrm{Y}_{2} \mathrm{O}_{3}$ in the $\mathrm{H}_{2}-\mathrm{N}_{2}$ atmosphere for $2 \mathrm{~h}$ during the series of infrared spectroscopic analysis in Fig. 6. Two adsorption bands of formate species were observed at 2906 and $2767 \mathrm{~cm}^{-1}$ for $\mathrm{Ni} / \mathrm{Al}_{2} \mathrm{O}_{3}$ and at 2852 and $2728 \mathrm{~cm}^{-1}$ for $\mathrm{Ni} / \mathrm{Y}_{2} \mathrm{O}_{3}$ in addition to the wavenumber range shown in Fig. 6. In the spectra for $\mathrm{Ni} / \mathrm{Al}_{2} \mathrm{O}_{3}$, the bands of $\mathrm{CO}$ formed on $\mathrm{Ni}$ disappeared within 20 min from the stop of $\mathrm{CO}_{2}$ supply, indicating that the $\mathrm{CO}$ species were desorbed and/or converted in the $\mathrm{H}_{2}$ atmosphere. In contrast, a slow decrease in the band intensity of formate species was confirmed. The previous literatures proposed that $\mathrm{CO}_{2}$ methanation over the $\mathrm{Ni} / \mathrm{Al}_{2} \mathrm{O}_{3}$ catalyst proceeds via the formation of $\mathrm{CO}$ intermediate. In that case, the $\mathrm{CO}$ species are dissociated into carbon and oxygen species, and these species are 
hydrogenated to form $\mathrm{CH}_{4}$ and water, respectively $[9,20]$. Because the dissociation of $\mathrm{CO}$ was reported to be the rate-determining step on $\mathrm{CO}_{2}$ methanation via the formation of $\mathrm{CO}$ intermediate [20], the stable $\mathrm{CO}$ species formed on $\mathrm{Ni}$ were observed by the infrared spectroscopic analysis in this study. On the contrary, at the present stage, it could not be judged whether the formate species contributed to the methanation reaction. For Ni/ $\mathrm{Y}_{2} \mathrm{O}_{3}$, the formate species were rapidly decomposed within $2 \mathrm{~h}$ relative to the carbonate-like species. The weak bands of $\mathrm{CO}$ species formed on $\mathrm{Ni}$ vanished within $20 \mathrm{~min}$ as observed for $\mathrm{Ni} / \mathrm{Al}_{2} \mathrm{O}_{3}$. Considering the more rapid decomposition of formate species and the higher catalytic activity for $\mathrm{CO}_{2}$ methanation, the formate species should serve as an intermediate in the reaction over the $\mathrm{Ni} / \mathrm{Y}_{2} \mathrm{O}_{3}$ catalyst. In the previous studies, the supported metal catalysts containing $\mathrm{CeO}_{2}$ and $\mathrm{CeO}_{2}-\mathrm{ZrO}_{2}$ materials promoted the decomposition of formate species, giving rise to high catalytic activity for $\mathrm{CO}_{2}$ methanation $[5,16,17]$. Accordingly, in this study, the support effect of $\mathrm{Y}_{2} \mathrm{O}_{3}$ on the decomposition of formate species would be responsible for the superior catalytic performance of $\mathrm{Ni} / \mathrm{Y}_{2} \mathrm{O}_{3}$. In contrast, the $\mathrm{CO}$ species may slightly contribute to the methanation reaction as an intermediate because their behavior over $\mathrm{Ni} / \mathrm{Y}_{2} \mathrm{O}_{3}$ was the same as that over $\mathrm{Ni} / \mathrm{Al}_{2} \mathrm{O}_{3}$. Over the less-active $\mathrm{Ni} / \mathrm{La}_{2} \mathrm{O}_{3}$ catalyst, hydrogen carbonates and formate species were not formed even in the presence of $\mathrm{H}_{2}$ and $\mathrm{CO}_{2}$ (see Fig. 6). This should be related to the $\mathrm{CO}_{2}-\mathrm{TPD}$ result, which showed the $\mathrm{CO}_{2}$ desorption at high temperatures. The in situ infrared spectroscopic analysis suggested that strong basic sites on Ni catalysts would have a negative effect on the activation of carbonates in $\mathrm{CO}_{2}$ methanation. Consequently, these results revealed that there was a possibility for the dependence of the support material on the dominant reaction path and the formed intermediate in $\mathrm{CO}_{2}$ methanation.

\section{Conclusions}

Various $\mathrm{Ni}$ catalysts supported on metal oxides were investigated for the activity of $\mathrm{CO}_{2}$ methanation and the species formed on their surface in the reaction. The $\mathrm{Ni} / \mathrm{Y}_{2} \mathrm{O}_{3}$ catalyst exhibited the highest $\mathrm{CH}_{4}$ yield below $350{ }^{\circ} \mathrm{C}$ among all the samples studied, while methane was scarcely produced over $\mathrm{Ni} / \mathrm{La}_{2} \mathrm{O}_{3}$ at $250{ }^{\circ} \mathrm{C}$. The $\mathrm{CO}_{2}$ desorption behavior of $\mathrm{Ni}$ catalysts suggested that the moderate basic sites should have a positive effect on the catalytic activity for $\mathrm{CO}_{2}$ methanation. The species formed on the surface during $\mathrm{CO}_{2}$ methanation was 
compared for $\mathrm{Ni} / \mathrm{Y}_{2} \mathrm{O}_{3}, \mathrm{Ni} / \mathrm{Al}_{2} \mathrm{O}_{3}$, and $\mathrm{Ni} / \mathrm{La}_{2} \mathrm{O}_{3}$. For $\mathrm{Ni} / \mathrm{Al}_{2} \mathrm{O}_{3}$, the $\mathrm{CO}$ species on Ni surface was specifically confirmed, indicating that $\mathrm{CO}_{2}$ methanation should proceed via the formation of $\mathrm{CO}$ intermediate. Only carbonates were formed over $\mathrm{Ni} / \mathrm{La}_{2} \mathrm{O}_{3}$ even under the methanation condition. In contrast, over $\mathrm{Ni} / \mathrm{Y}_{2} \mathrm{O}_{3}$ the carbonate-like species were converted to formate species by introducing $\mathrm{H}_{2}$ to the $\mathrm{CO}_{2}$ atmosphere, followed by the decomposition of formate species in the $\mathrm{H}_{2}$ atmosphere. The promotion of the decomposition of formate species over the $\mathrm{Ni} / \mathrm{Y}_{2} \mathrm{O}_{3}$ catalyst would be responsible for its high catalytic activity. Although the reaction mechanism of $\mathrm{CO}_{2}$ methanation over $\mathrm{Ni}$ catalysts has not been elucidated sufficiently, the mechanism should be different depending on the catalysts. Thus, further investigations on the reaction mechanism as well as the search for new materials are requested for the development of highly-active catalysts.

\section{Acknowledgment}

The authors express thanks to Mr. Ozeki, Department of Energy and Hydrocarbon Chemistry, Kyoto University, for the TEM observations.

\section{References}

[1] W. Wang, J. Gong, Front. Chem. Sci. Eng. 5 (2011) 2.

[2] M. A. A. Aziz, A. A. Jalil, S. Triwahyono, A. Ahmad, Green Chem. 17 (2015) 2647.

[3] K. R. Thampi, J. Kiwi, M. Grätzel, Nature 327 (1987) 506.

[4] S. Sharma, Z Hu, P. Zhang, E. W. McFarland, H. Metiu, J. Catal. 278 (2011) 297.

[5] S. Tada, O. J. Ochieng, R. Kikuchi, T. Haneda, H. Kameyama, Int. J. Hydrogen Energy 39 (2014) 10090.

[6] G. Garbarino, D. Bellotti, P. Riani, L. Magistri, G. Busca, Int. J. Hydrogen Energy 40 (2015) 9171.

[7] A. Karelovic, P. Ruiz, J. Catal. 301 (2013) 141.

[8] J.-N. Park, E. W. McFarland, J. Catal. 266 (2009) 92.

[9] S. Fujita, M. Nakamura, T. Doi, N. Takezawa, Appl. Catal. A: Gen. 104 (1993) 87.

[10] G. Garbarino, P. Riani, L. Magistri, G. Busca, Int. J. Hydrogen Energy 39 (2014) 11557.

[11] G. D. Weatherbee, C. H. Bartholomew, J. Catal. 68 (1981) 67.

[12] G. D. Weatherbee, C. H. Bartholomew, J. Catal. 77 (1982) 460. 
[13] I. Graça, L. V. González, M. C. Bacariza, A. Fernandes, C. Henriques, J. M. Lopes, M. F. Ribeiro, Appl. Catal. B: Environ. 147 (2014) 101.

[14] A. Westermann, B. Azambre, M. C. Bacariza, I. Graça, M. F. Ribeiro, J. M. Lopes, C. Henriques, Appl. Catal. B: Environ. 174-175 (2015) 120.

[15] S. Tada, T. Shimizu, H. Kameyama, T. Haneda, R. Kikuchi, Int. J. Hydrogen Energy 37 (2012) 5527.

[16] P. A. Ussa Aldana, F. Ocampo, K. Kobl, B. Louis, F. Thibault-Starzyk, M. Daturi, P. Bazin, S. Thomas, A. C. Roger, Catal. Today 215 (2013) 201.

[17] Q. Pan, J. Peng, T. Sun, S. Wang, S. Wang, Catal. Commun. 45 (2014) 74.

[18] Q. Pan, J. Peng, S. Wang, S. Wang, Catal. Sci. Technol. 4 (2014) 502.

[19] P. Bothra, G. Periyasamy, S. K. Pati, Phys. Chem. Chem. Phys. 15 (2013) 5701.

[20] J. Ren, H. Guo, J. Yang, Z. Qin, J. Lin, Z. Li, Appl. Surf. Sci. 351 (2015) 504.

[21] C. Schild, A. Wokaun, A. Baiker, J. Mol. Catal. 63 (1990) 223.

[22] H. Lu, X. Yang, G. Gao, K. Wang, Q. Shi, J. Wang, C. Han, J. Liu, M. Tong, X. Liang, C. Li, Int. J. Hydrogen Energy 39 (2014) 18894.

[23] L. Zhou, Q. Wang, L. Ma, J. Chen, J. Ma, Z. Zi, Catal. Lett. 145 (2015) 612.

[24] E. M. Köck, M. Kogler, T. Bielz, B. Klötzer, S. Penner, J. Phy. Chem. C 117 (2013) 17666.

[25] C. Hu, Y. Chen, P. Li, H. Min, Y. Chen, A. Tian, J. Mol. Catal. A: Chem. 110 (1996) 163.

[26] F. Solymosi, M. Pásztor, J. Catal. 104 (1987) 312. 
Table 1 Volume per unit weight of as-prepared $10 \mathrm{wt} . \% \mathrm{Ni} /$ metal oxide catalysts $\left(\mathrm{Al}_{2} \mathrm{O}_{3}, \mathrm{Y}_{2} \mathrm{O}_{3}, \mathrm{ZrO}_{2}, \mathrm{La}_{2} \mathrm{O}_{3}, \mathrm{CeO}_{2}\right.$, $\left.\mathrm{Sm}_{2} \mathrm{O}_{3}\right)$

\begin{tabular}{ccccccc}
\hline Sample & $\mathrm{Ni} / \mathrm{Al}_{2} \mathrm{O}_{3}$ & $\mathrm{Ni} / \mathrm{Y}_{2} \mathrm{O}_{3}$ & $\mathrm{Ni} / \mathrm{ZrO}_{2}$ & $\mathrm{Ni} / \mathrm{La}_{2} \mathrm{O}_{3}$ & $\mathrm{Ni} / \mathrm{CeO}_{2}$ & $\mathrm{Ni} / \mathrm{Sm}_{2} \mathrm{O}_{3}$ \\
\hline Volume per unit weight $/ \mathrm{cm}^{3} \mathrm{~g}^{-1}$ & 0.202 & 0.174 & 0.150 & 0.166 & 0.126 & 0.143 \\
\hline
\end{tabular}




\section{Figure captions}

Fig. 1 XRD patterns of $10 \mathrm{wt} . \% \mathrm{Ni} /$ metal oxide catalysts $\left(\mathrm{Al}_{2} \mathrm{O}_{3}, \mathrm{Y}_{2} \mathrm{O}_{3}, \mathrm{ZrO}_{2}, \mathrm{La}_{2} \mathrm{O}_{3}, \mathrm{CeO}_{2}, \mathrm{Sm}_{2} \mathrm{O}_{3}\right)$ after reducing at $600{ }^{\circ} \mathrm{C}$ for $3 \mathrm{~h}$ in $10 \% \mathrm{H}_{2}-90 \% \mathrm{~N}_{2}$.

Fig. $2 \mathrm{H}_{2}-\mathrm{TPR}$ profiles of $10 \mathrm{wt} . \% \mathrm{Ni} /$ metal oxide catalysts $\left(\mathrm{Al}_{2} \mathrm{O}_{3}, \mathrm{Y}_{2} \mathrm{O}_{3}, \mathrm{ZrO}_{2}, \mathrm{La}_{2} \mathrm{O}_{3}, \mathrm{CeO}_{2}, \mathrm{Sm}_{2} \mathrm{O}_{3}\right)$. Atmosphere: $4 \% \mathrm{H}_{2} /$ Ar. Heating rate: $10{ }^{\circ} \mathrm{C} \mathrm{min}^{-1}$.

Fig. $3 \mathrm{CO}_{2}$ desorption rates over $10 \mathrm{wt}$ \% $\mathrm{Ni} /$ metal oxide catalysts $\left(\mathrm{Al}_{2} \mathrm{O}_{3}, \mathrm{Y}_{2} \mathrm{O}_{3}, \mathrm{ZrO}_{2}, \mathrm{La}_{2} \mathrm{O}_{3}, \mathrm{CeO}_{2}, \mathrm{Sm}_{2} \mathrm{O}_{3}\right)$. Atmosphere: He. Heating rate: $10^{\circ} \mathrm{C} \mathrm{min}^{-1}$.

Fig. 4 (a) $\mathrm{CO}_{2}$ conversion, and (b) $\mathrm{CH}_{4}$ and (c) $\mathrm{CO}$ yields in $\mathrm{CO}_{2}$ methanation over $10 \mathrm{wt} \% \mathrm{Ni} /$ metal oxide catalysts $\left(\mathrm{Al}_{2} \mathrm{O}_{3}, \mathrm{Y}_{2} \mathrm{O}_{3}, \mathrm{ZrO}_{2}, \mathrm{La}_{2} \mathrm{O}_{3}, \mathrm{CeO}_{2}, \mathrm{Sm}_{2} \mathrm{O}_{3}\right)$. Reaction gas: $10 \% \mathrm{CO}_{2}-40 \% \mathrm{H}_{2}-50 \% \mathrm{~N}_{2}$. Low S.V.: $20,0001 \mathrm{~kg}^{-1} \mathrm{~h}^{-1}$. High S.V.: $30,0001 \mathrm{~kg}^{-1} \mathrm{~h}^{-1}$.

Fig. 5 Time courses of (a) $\mathrm{CO}_{2}$ conversion, and (b) $\mathrm{CH}_{4}$ and $\mathrm{CO}$ yields in $\mathrm{CO}_{2}$ methanation over $10 \mathrm{wt} . \% \mathrm{Ni} / \mathrm{Al}_{2} \mathrm{O}_{3}$, $\mathrm{Ni} / \mathrm{Y}_{2} \mathrm{O}_{3}$, and $\mathrm{Ni} / \mathrm{Sm}_{2} \mathrm{O}_{3}$. Reaction gas: $10 \% \mathrm{CO}_{2}-40 \% \mathrm{H}_{2}-50 \% \mathrm{~N}_{2}$. S.V.: $20,0001 \mathrm{~kg}^{-1} \mathrm{~h}^{-1}$.

Fig. 6 Infrared spectra of species formed on (A) Ni/La $\mathrm{O}_{3}$, (B) $\mathrm{Ni} / \mathrm{Al}_{2} \mathrm{O}_{3}$, and (C) $\mathrm{Ni} / \mathrm{Y}_{2} \mathrm{O}_{3}$ at $200{ }^{\circ} \mathrm{C}$ after holding (a) in the $\mathrm{CO}_{2}-\mathrm{N}_{2}$ atmosphere for $30 \mathrm{~min}$, (b) in the $\mathrm{CO}_{2}-\mathrm{H}_{2}-\mathrm{N}_{2}$ atmosphere for $30 \mathrm{~min}$, and (c) in the $\mathrm{H}_{2}-\mathrm{N}_{2}$ atmosphere for 1 min. These spectra were recorded with sequential supply of (a), (b), and (c).

Fig. 7 Infrared spectra of species formed on (A) $\mathrm{Ni} / \mathrm{Al}_{2} \mathrm{O}_{3}$ and (B) $\mathrm{Ni} / \mathrm{Y}_{2} \mathrm{O}_{3}$ under the prolonged exposure to $\mathrm{H}_{2}-\mathrm{N}_{2}$ atmosphere for $2 \mathrm{~h}$ in the series of infrared spectroscopic analysis in Fig. 5. 


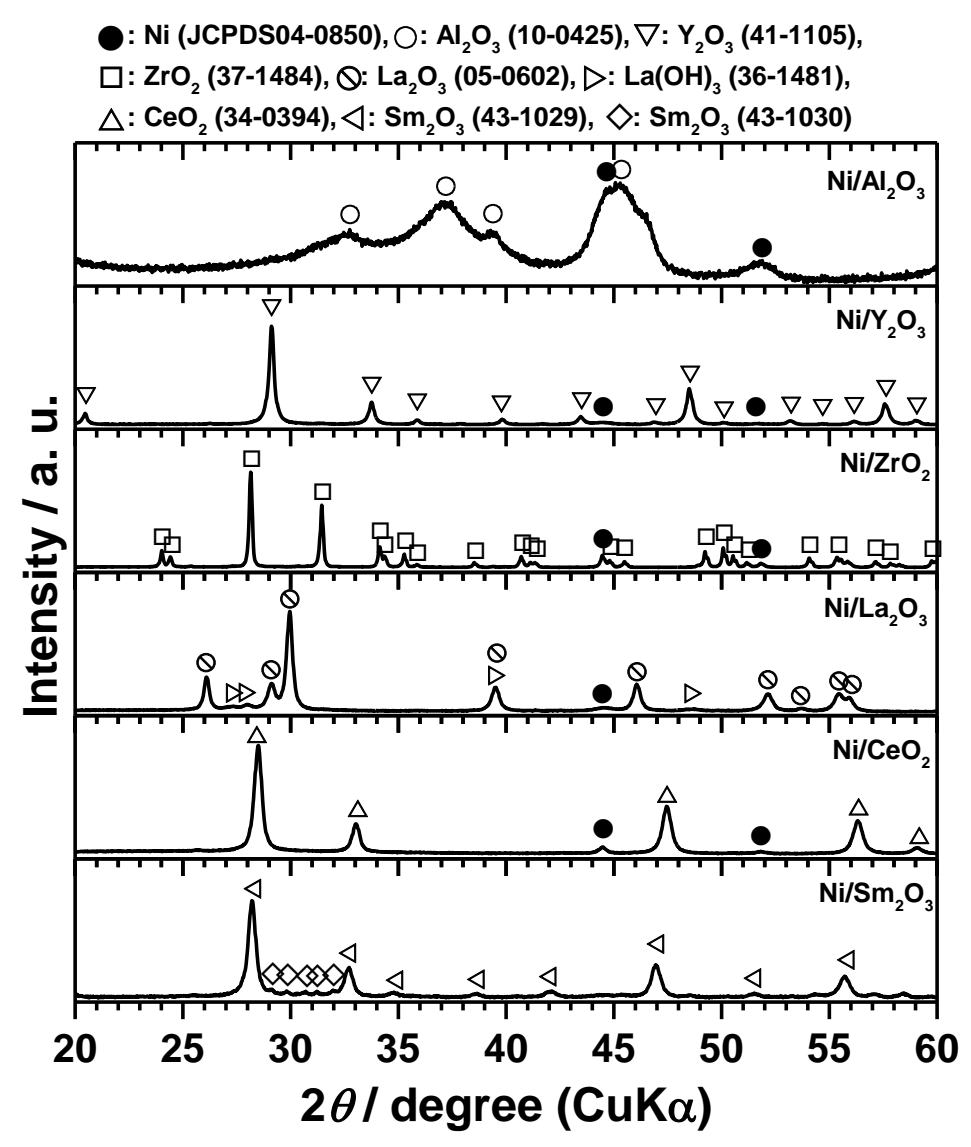

Fig. 1 H. Muroyama et al. 


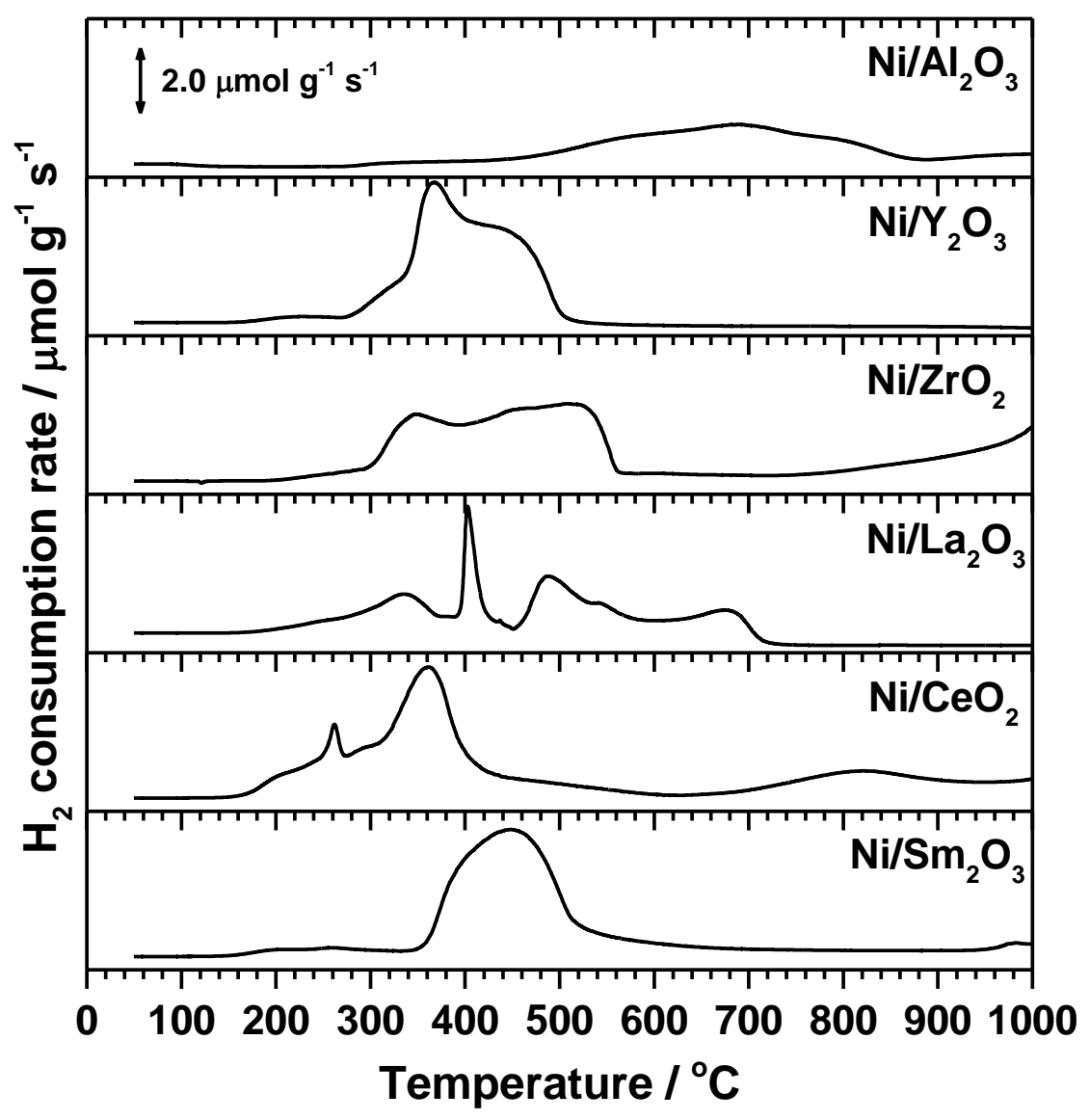

Fig. 2 H. Muroyama et al. 


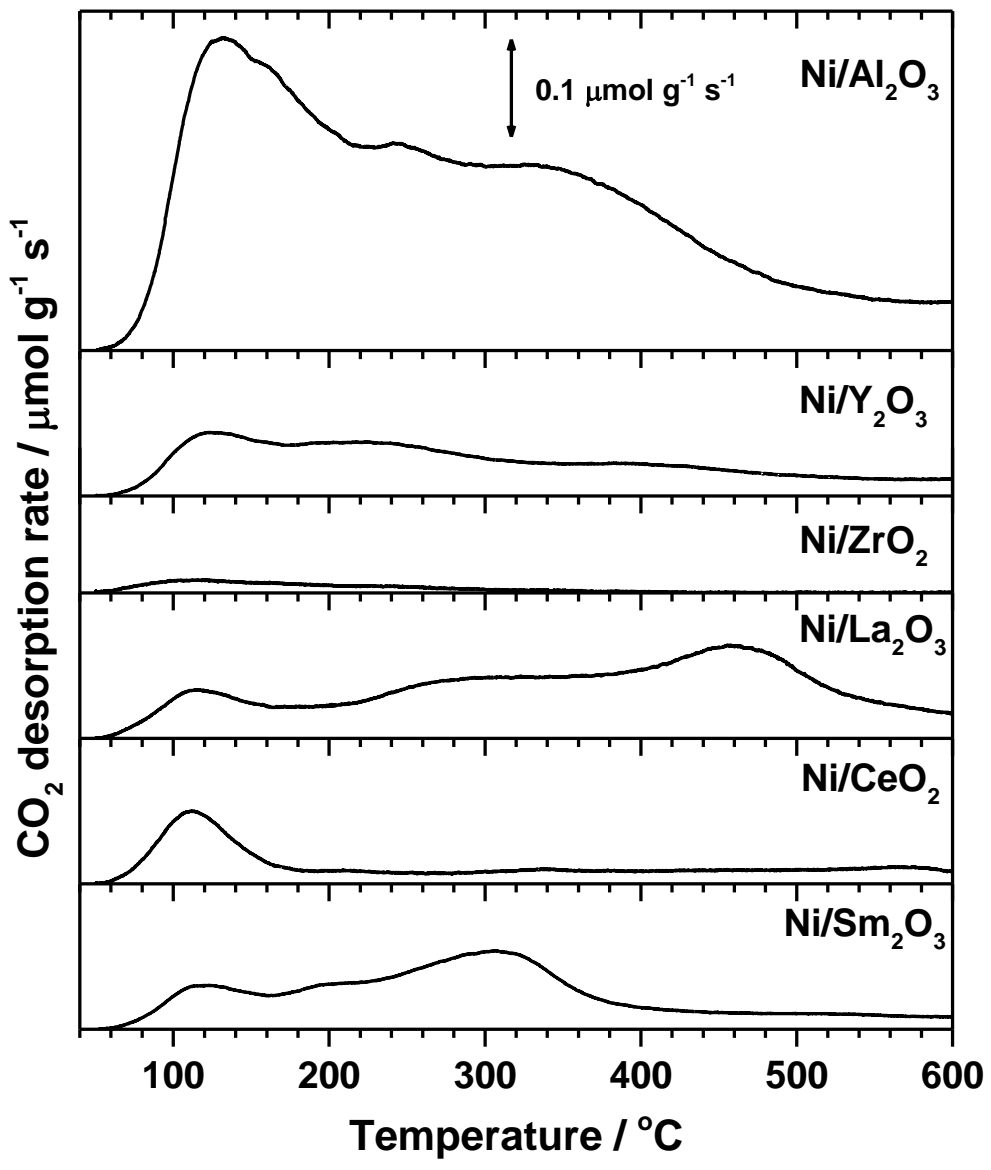

Fig. 3 H. Muroyama et al. 


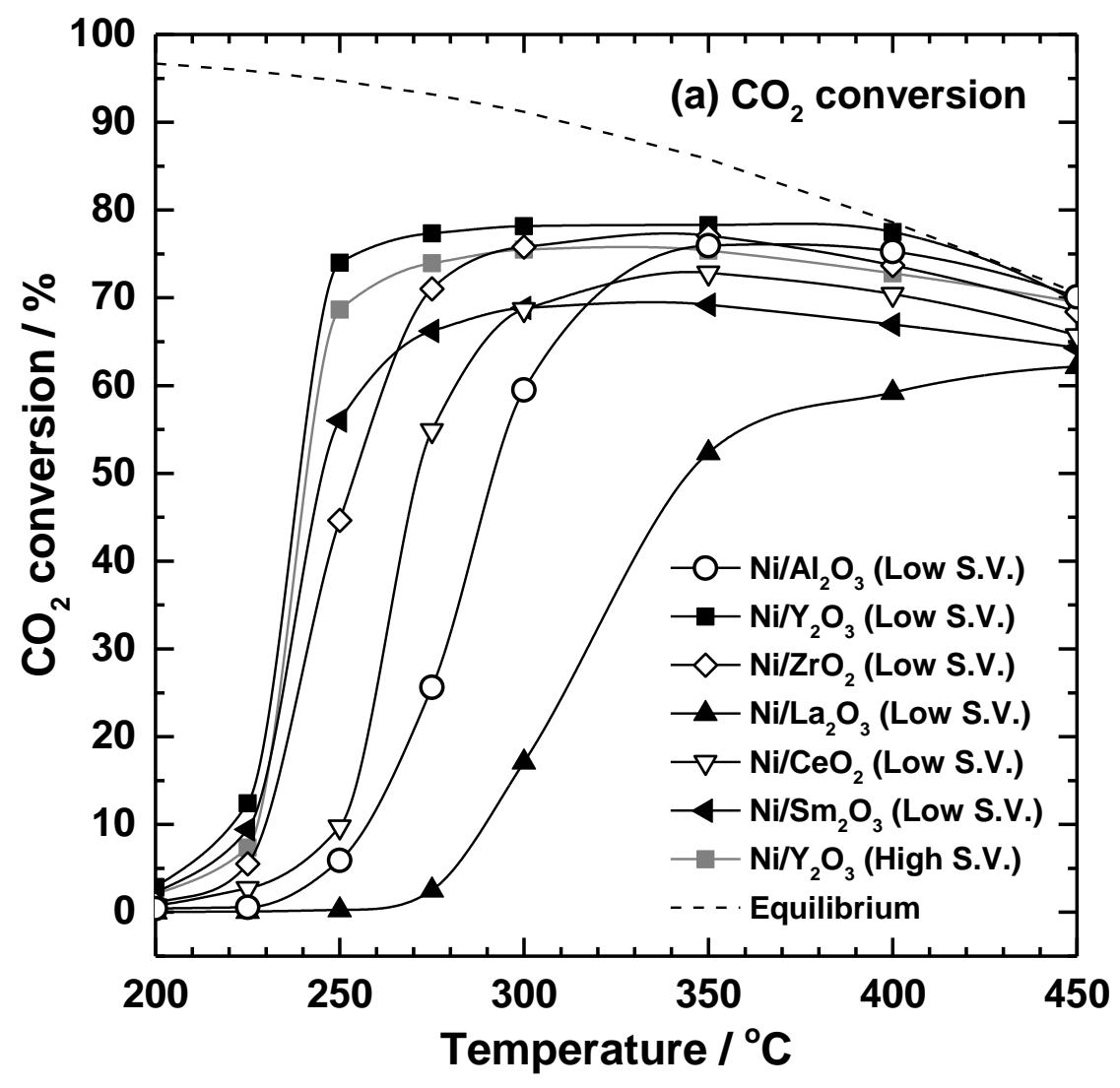

Fig. 4(a) H. Muroyama et al. 


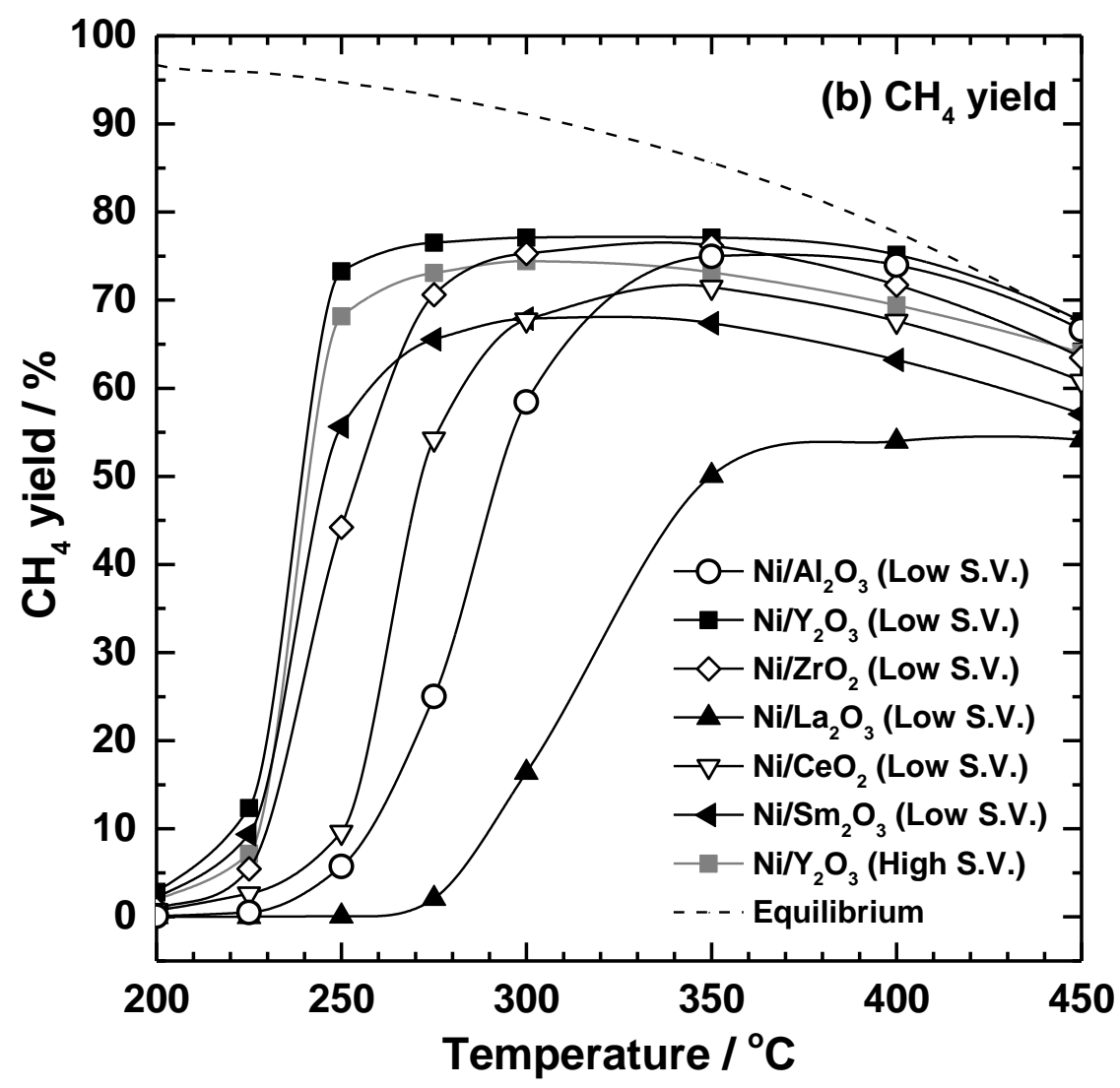

Fig. 4(b) H. Muroyama et al. 


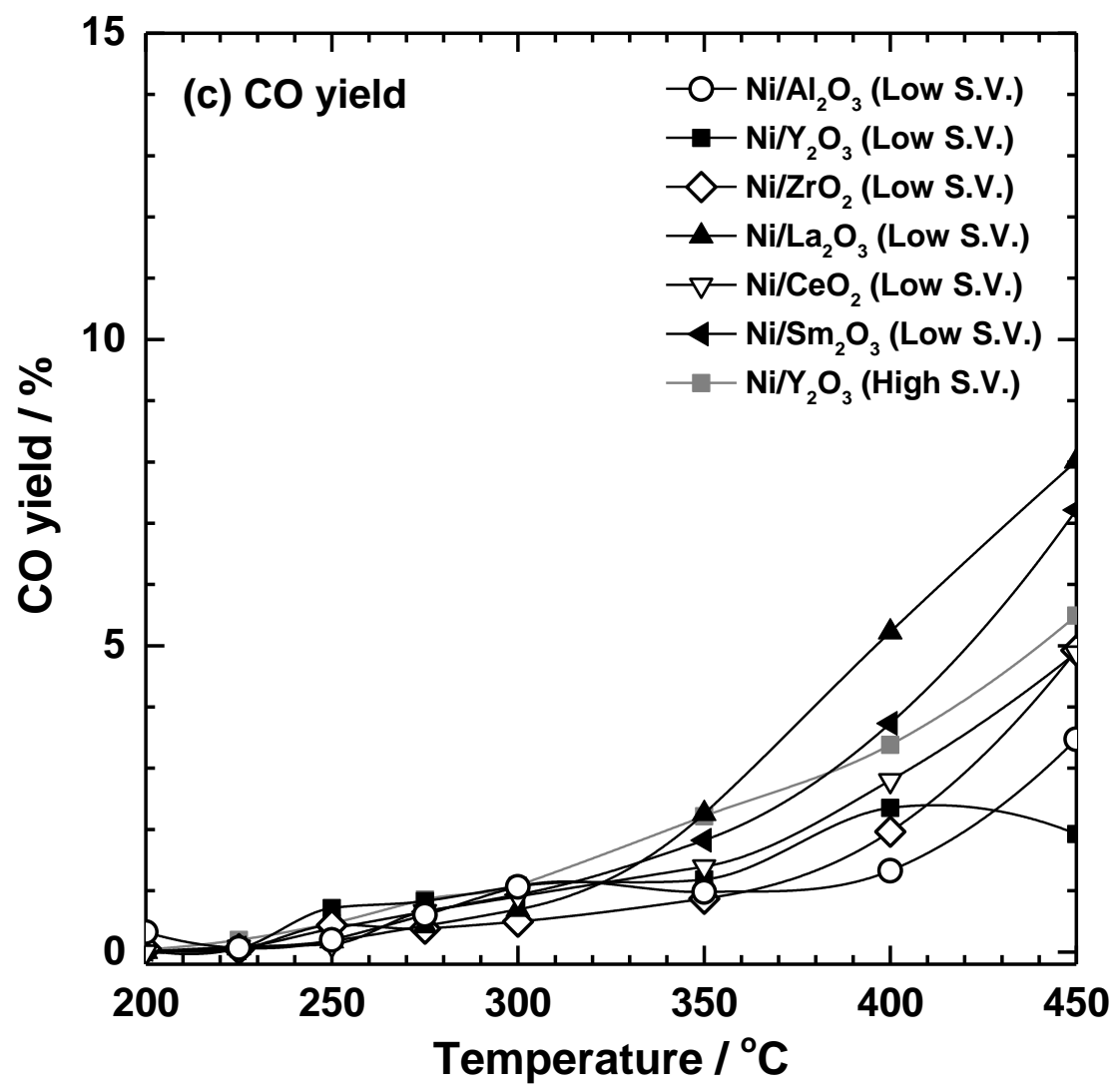

Fig. 4(c) H. Muroyama et al. 


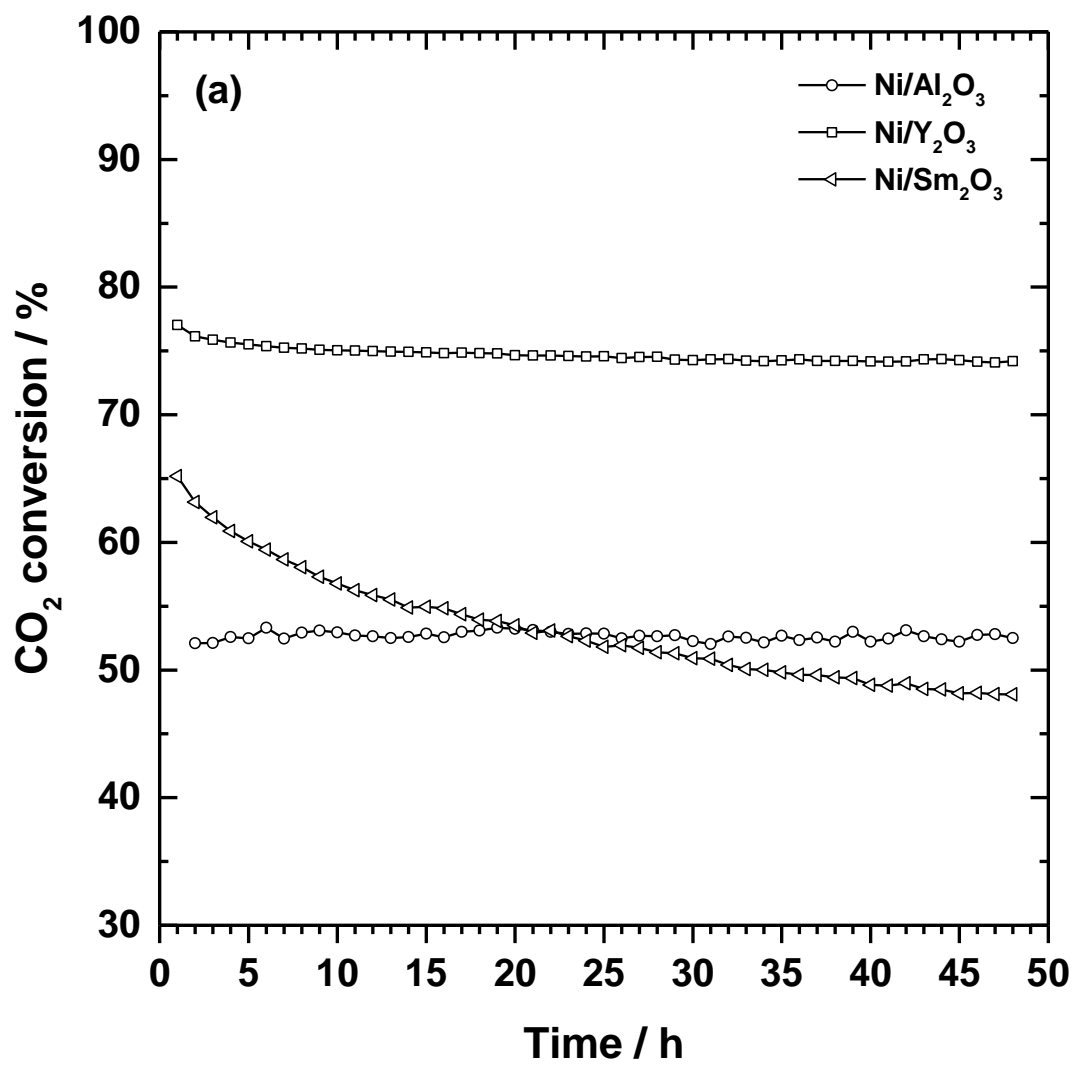

Fig. 5(a) H. Muroyama et al. 


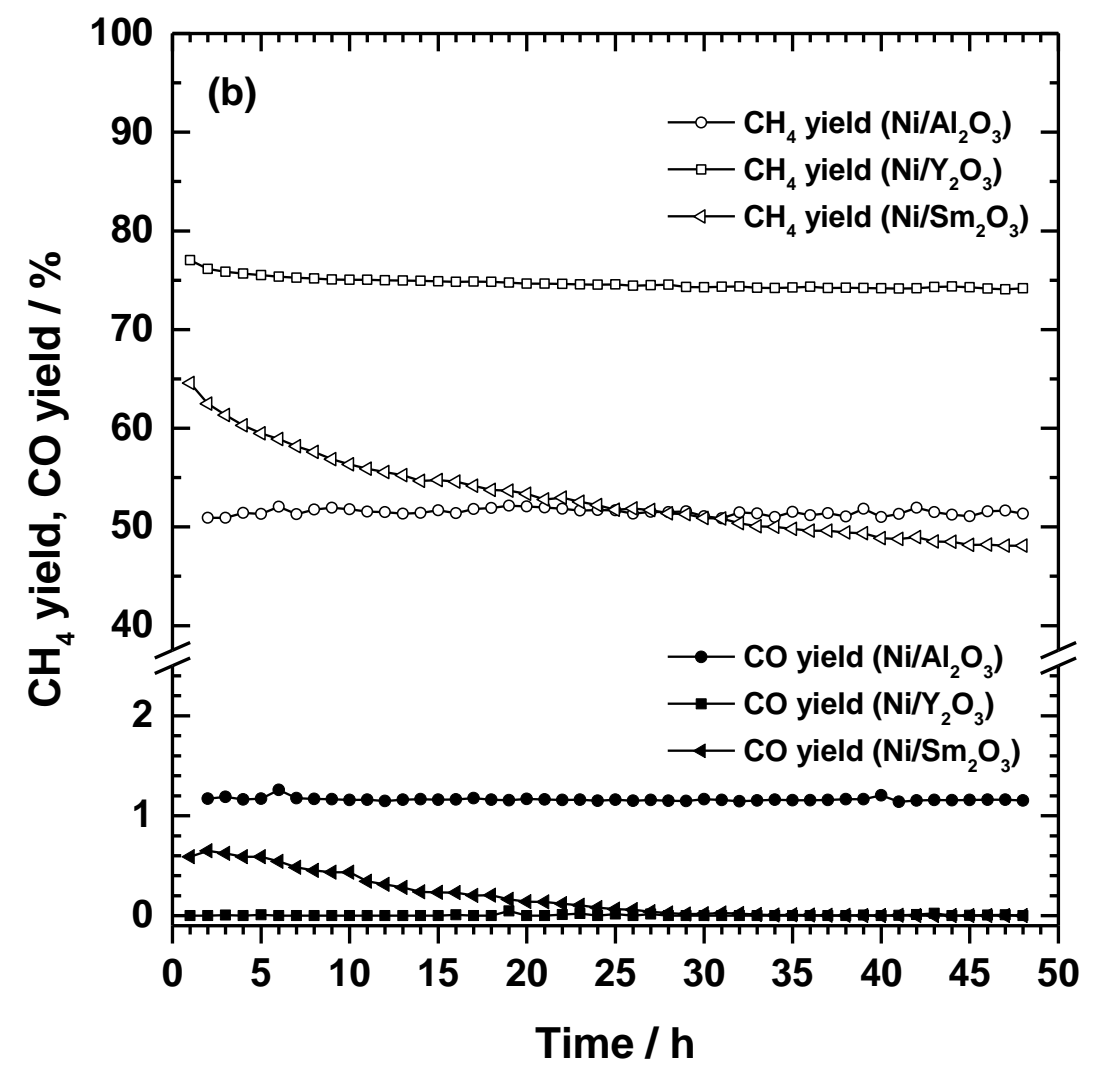

Fig. 5(b) H. Muroyama et al. 


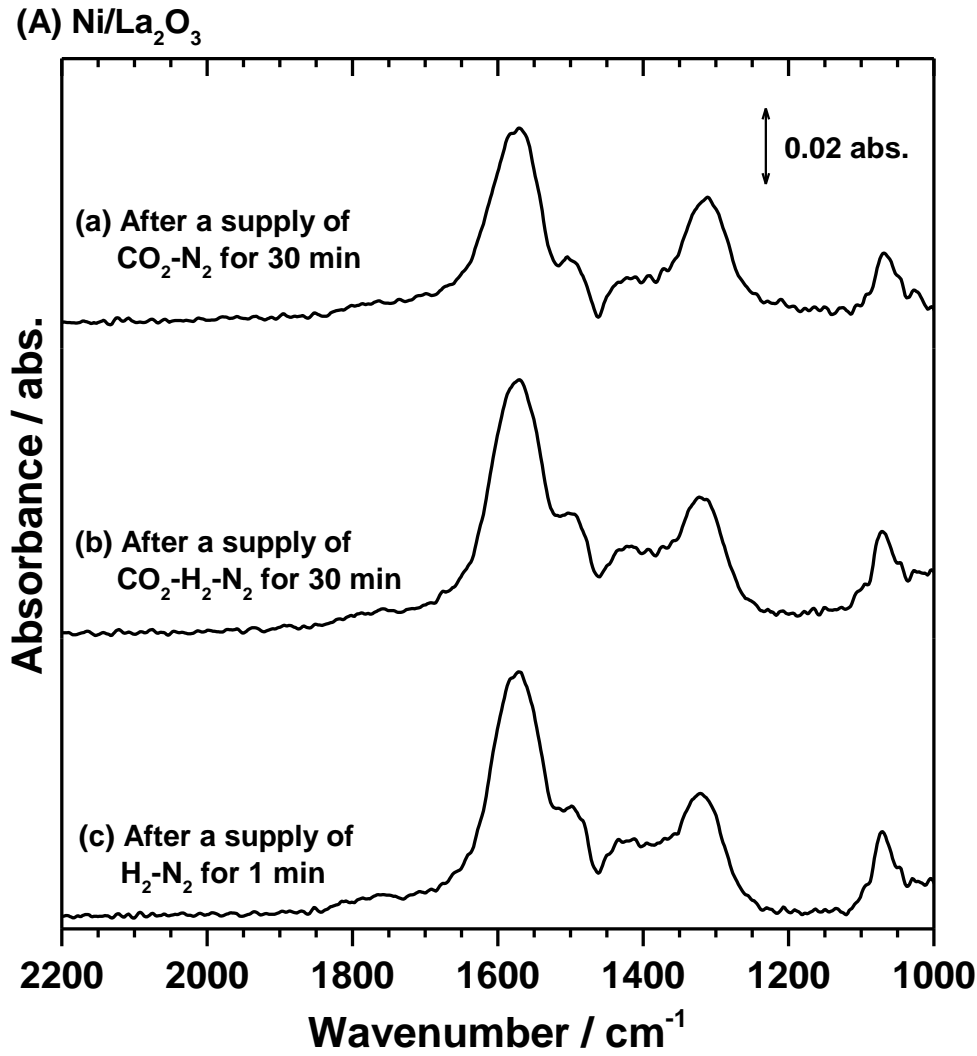

Fig. 6(A) H. Muroyama et al. 


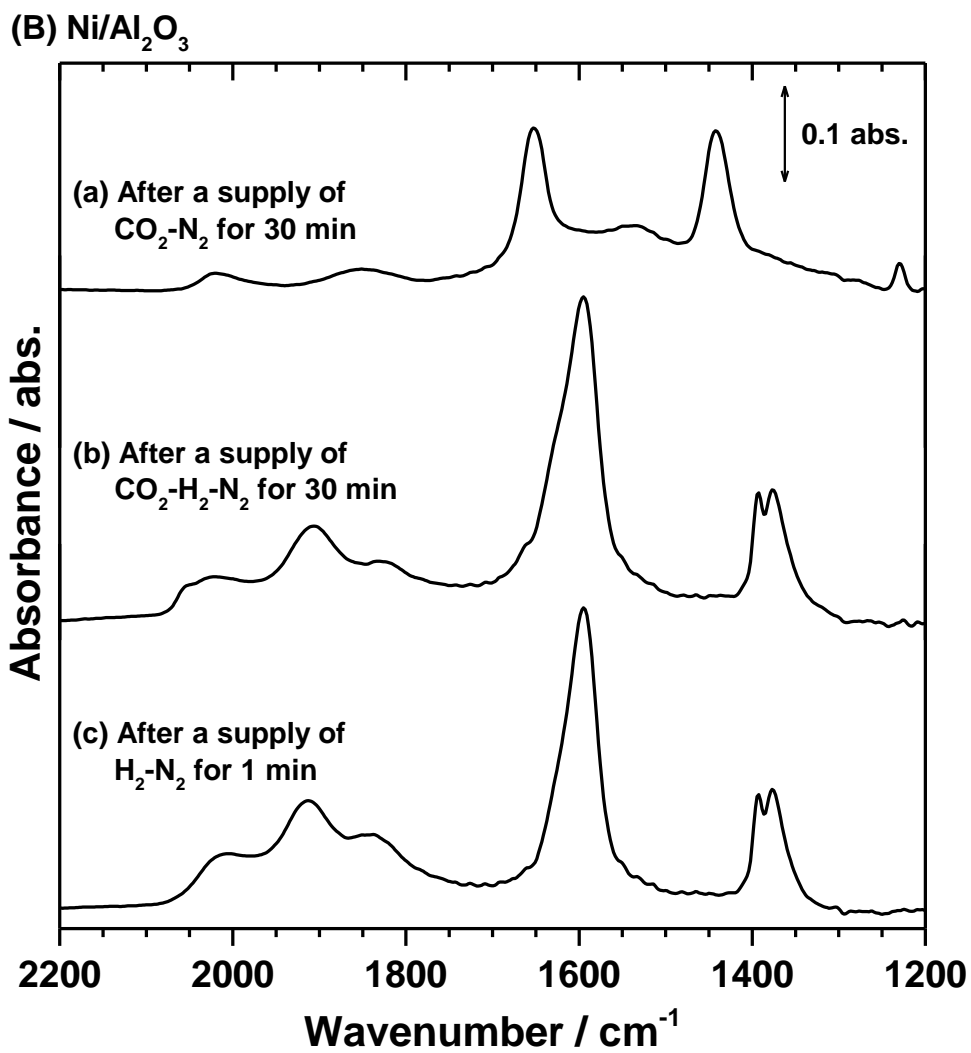

Fig. 6(B) H. Muroyama et al. 


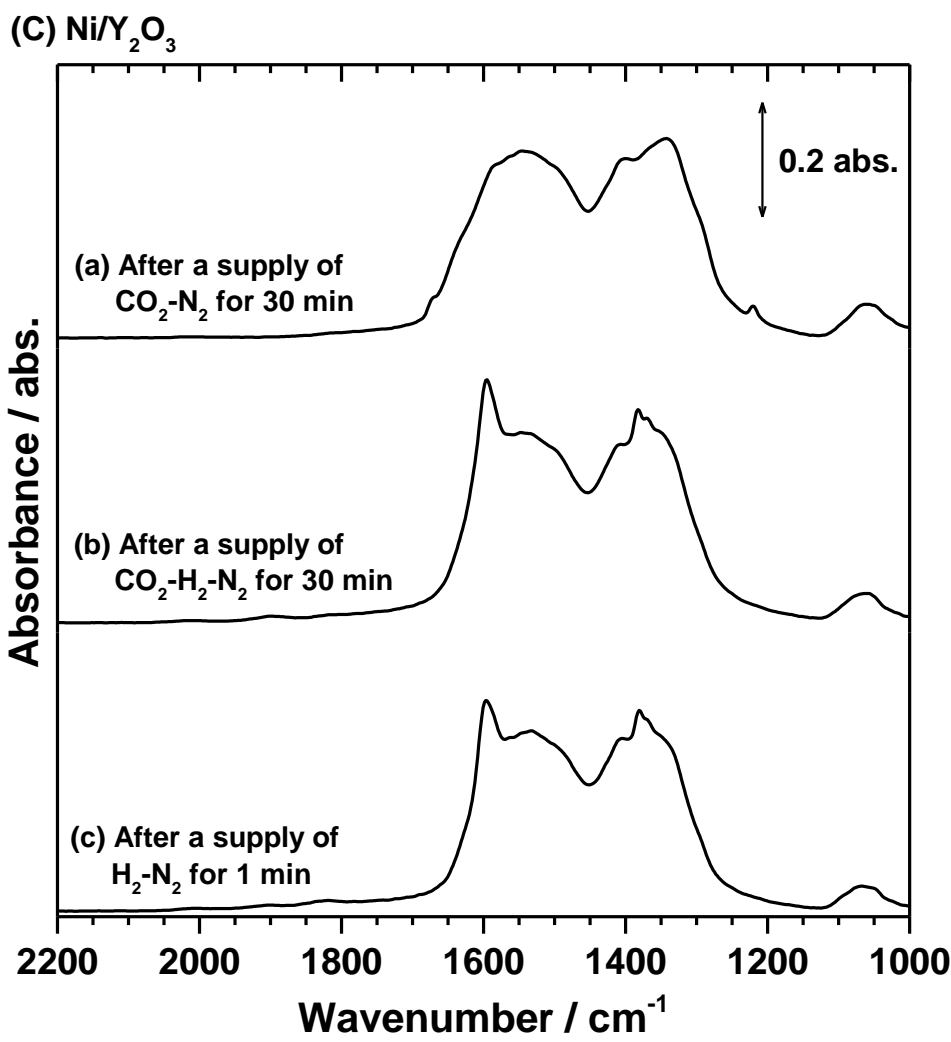

Fig. 6(C) H. Muroyama et al. 


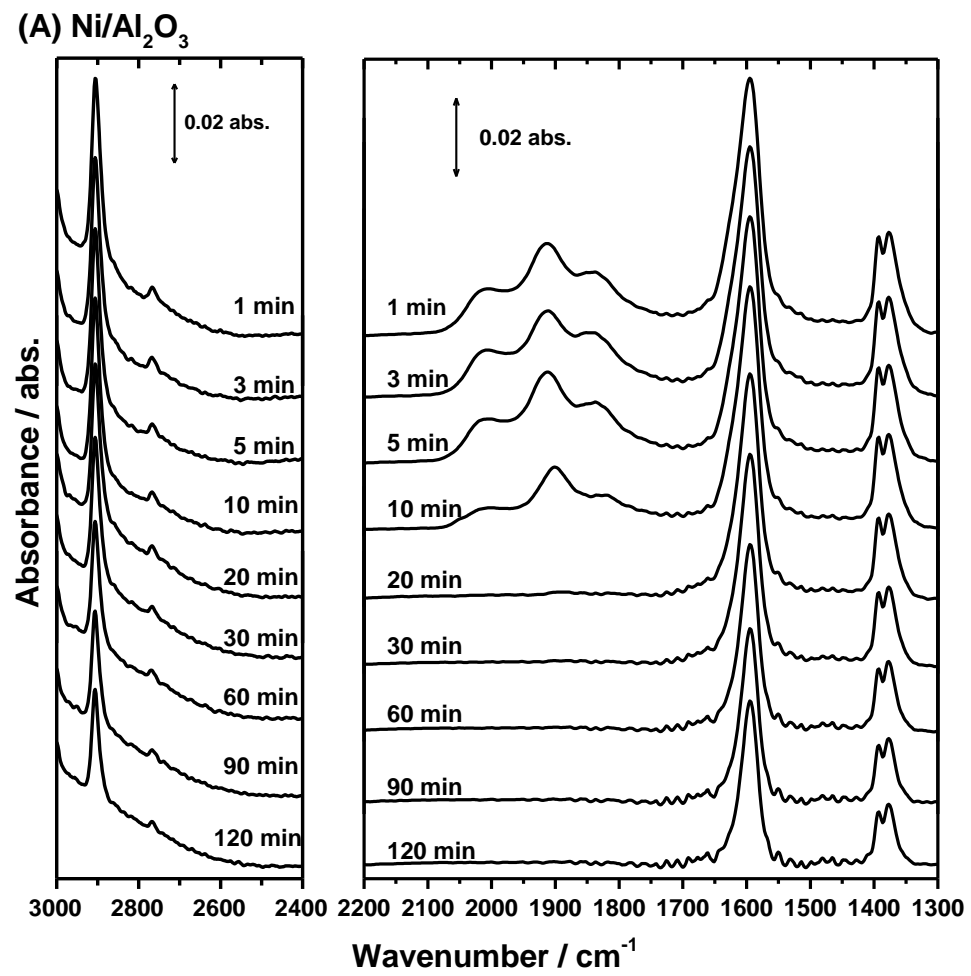

Fig. 7(A) H. Muroyama et al. 
(B) $\mathrm{Ni} / \mathrm{Y}_{2} \mathrm{O}_{3}$

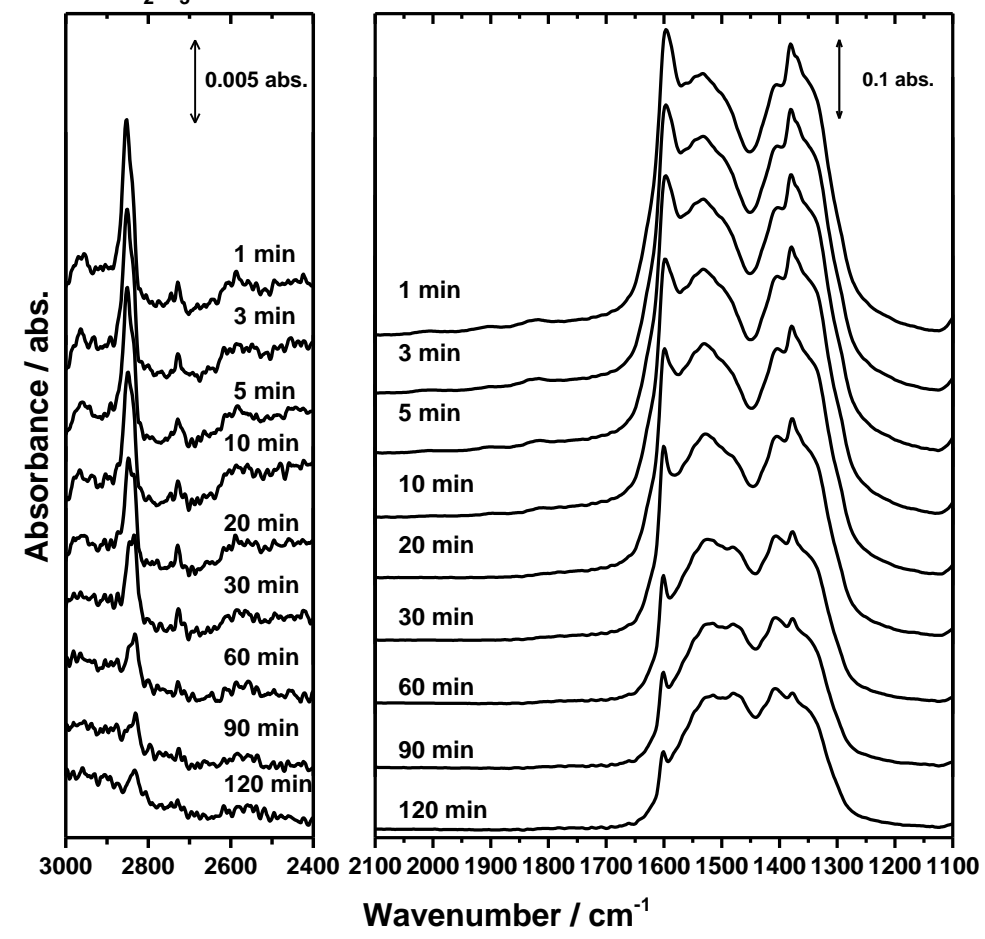

Fig. 7(B) H. Muroyama et al. 